\title{
Trade Policy and the China Syndrome
}

\author{
Lorenzo Trimarchi
}

SERIES Working PAPERS N. 05/2020

SERIES sono pubblicati a cura del Dipartimento di Scienze economiche e metodi matematici dell'Università degli Studi di Bari "Aldo Moro". I lavori riflettono esclusivamente le opinioni degli autori e non impegnano la responsabilità del Dipartimento. SERIES vogliono promuovere la circolazione di studi ancora preliminari e incompleti, per suscitare commenti critici e suggerimenti. Si richiede di tener conto della natura provvisoria dei lavori per eventuali citazioni o per ogni altro uso.
SERIES are published under the auspices of the Department of Economics of the University of Bari. Any opinions expressed here are those of the authors and not those of the Department. Often SERIES divulge preliminary or incomplete work, circulated to favor discussion and comment. Citation and use of these paper should consider their provisional character. 


\title{
Trade Policy And the China Syndrome*
}

\author{
Lorenzo Trimarchi \\ Université de Namur
}

April 2020

\begin{abstract}
The recent backlash against free trade is partially motivated by the decline in manufacturing employment due to rising import competition from China. Previous studies about the "China syndrome" neglect the role of trade policy. This is surprising, given that politicians in highincome countries have extensively used antidumping $(\mathrm{AD})$ measures to protect their economies from rising Chinese imports. In this paper, I estimate the causal effect of trade protection on imports and employment, by constructing a new instrument for AD measures based on industries' importance in swing states and experience in filing AD petitions. I show that AD duties have reduced import competition, decreasing the annual growth rate of US imports from China by 0.40 percentage points on average. They have also helped contain the China syndrome, by increasing the annual growth rate of employment in protected industries by 0.07 percentage points. These results show that protectionist instruments allowed under GATT/WTO rules can be used to attenuate the effects of import competition on employment.
\end{abstract}

JEL Classification: F13, F14, F16, J20

Keywords: Antidumping, Import Competition, Manufacturing Jobs, US-China Trade Relations.

\footnotetext{
*I am very grateful to Paola Conconi and Maurizio Zanardi for their invaluable guidance and support. I wish to thank Gani Aldashev, Tommaso Aquilante, Stefan Bergheimer, Michael Blanga-Gubbay, Andrew Bernard, Chad Bown, Guidogiorgio Bodrato, Guilhem Cassan, Michael Castanheira, Angela Capolongo, Arnaud Costinot, Aksel Erbahar, Sourafel Girma, Vincenzo Maccarrone, Glenn Magerman, Luigi Minale, Gianmarco Ottaviano, Marco Pagano, Mathieu Parenti, Marco Pelosi, Alexander Rohlf, Thomas Sampson, André Sapir, Annalisa Scognamiglio, Jan Stuhler, Denni Tommasi and Lorenzo Tondi for their comments and suggestions. I wish to thank the participants at the ENTER Jamboree Conference 2017 in London, the ETSG Annual Conference in Florence, the 17th GEP/CEPR Postgraduate Conference in Nottingham, the 23rd DEGIT Conference in Moscow, the 8th IOSE Conference in St. Petersburg, the 10th EGI Conference in Bari, the 14th ISGEP Workshop in Trento and seminar audiences at the Universidad de Madrid Carlos III, the Bank of England, the London School of Economics, the University of Naples Federico II, the Université libre de Bruxelles, the Bank of Spain, Aarhus University, the Université de Namur, the Université Catholique de Louvain, and the Bank of Italy. Research on this project was financially supported by the Excellence of Science (EOS) Research project of FNRS O020918F. All errors are my own. Address for correspondence: Université de Namur (CERPE), Department of Economics, Address: Rempart de la Vierge 8, B-5000 Namur (Belgium). Email: lorenzo.trimarchi@unamur.be.
} 


\section{Introduction}

Recent years have seen an unprecedented backlash against international trade and globalization more generally. Rising competition from China has contributed to this backlash. Between 1990 and 2011, the share of global manufacturing exports originating from China surged from $2 \%$ to $16 \%$. China's emergence as a trading power has been driven almost entirely by deep economic reforms enacted by China in the 1980s and 1990s, which were further extended when it joined the World Trade Organization (WTO) in 2001.

Politicians and economists have pointed their fingers at import competition from China as the cause of the decline in manufacturing jobs in high-income countries. In the United States, President Donald Trump has argued that trade with China is responsible for the "closure of more than 50,000 factories and the loss of tens of millions of jobs," concluding that the "WTO was not a good deal for America then and it's a bad deal now." ${ }^{2}$ A series of influential studies have also emphasized the "China syndrome," i.e. the negative impact of rising import competition from China on US employment. Focusing on US local labor markets, Autor et al. (2013) find that exposure to Chinese import competition explains $44 \%$ of the decline in manufacturing employment between 1991 and 2007. Exploiting variation in exposure across industries, Acemoglu et al. (2016) estimate that around $10 \%$ of the realized decline in US manufacturing jobs between 1999 and 2011 was due to increased import penetration from China.

The academic debate on the China syndrome has so far neglected the role of trade policy. This is somewhat surprising, given that governments around the world have extensively used various forms of contingent protection to shelter domestic industries from increased import competition even before the so-called "Trump Tariffs." For example, between 1988 and 2016, the number of antidumping $(\mathrm{AD})$ duties applied by the United States against China increased from 10 to 105 (see Figure A-1 in the Appendix), while the average antidumping duty increased from $44.8 \%$ to $147.7 \%$ (see Figure A-2). The share of Chinese imports covered by US AD duties has also been steadily increasing during this period (see Figure A-3).

This is the first paper to document this dramatic increase in US protection against China. The main goal of my analysis is to examine whether trade policy has helped to contain the negative effects of Chinese import competition. I focus on AD duties, which are by far the most widely used protectionist measures allowed by GATT/WTO rules. ${ }^{2}$

\footnotetext{
${ }^{1}$ Donald J. Trump, "United States-China Trade Reform Plan". Available at https://www.donaldjtrump.com.

${ }^{2}$ WTO rules allow member countries to use three forms of contingent protection: AD duties, countervailing duties, and safeguards. Antidumping duties are tariffs that can be imposed when a product is sold by a foreign firm below a "fair value"; that is, below the price charged in the firm's domestic market or, alternatively, below the production cost. Countervailing duties are tariffs that can be introduced when foreign producers benefit from illegal subsidies provided by their governments. Safeguards are special measures that can be introduced when imports cause, or threaten to cause, domestic market disruption, even in the absence of unfair behavior by a foreign firm or government. Antidumping has become the most commonly used policy tool through which industries seek and obtain protection from their governments (Zanardi, 2006). As shown in Figure A-1 in the Appendix, the number of AD
} 
A first look at the data suggests that AD protection may have helped to shelter US manufacturing jobs from Chinese competition. During 1988-2016, employment fell by $25 \%$ in industries implementing at least one AD measure against China, and by $38 \%$ in non-protected industries. However, this simple correlation between protection and employment can be misleading. As discussed in Section 4, identifying a causal link is very challenging, given that ordinary least squares (OLS) regressions suffer from both a simultaneity and an omitted-variable bias, which can lead to inconsistent estimates. The simultaneity bias has already been discussed by Trefler (1993). He shows that trade barriers and trade flows are jointly determined: an increase in AD has a negative impact on imports, while a rise in imports increases the demand for protection. Furthermore, the presence of unobservable shocks at the industry level worsens the endogeneity problem of an omitted-variable bias.

The main contribution of this paper is to develop a novel methodology to identify the causal effects of trade protection. I construct an instrument for $\mathrm{AD}$ duties, combining information on the importance of industries in swing states and on their experience at filing AD petitions. The instrument has two components, which exploit exogenous variation in supply and demand for AD protection.

The first component of my instrument builds on the literature on the political economy of trade policy. Previous studies show that US trade policy is biased towards the interests of swing states (e.g., Muûls and Petropoulou, 2013; Conconi et al., 2017; Ma and McLaren, 2018) and that AD decisions respond to domestic political interests (e.g., Finger et al., 1982). Following this literature, I exploit changes in which states are considered swing states across electoral cycles and differences in various industries' presence across states to capture exogenous variation in supply for protection. These studies suggest that key institutions involved in AD decisions in the United States — the US Department of Commerce and the US International Trade Commission - are more likely to respond positively to $\mathrm{AD}$ petitions when they come from industries that are important in key battleground states. $^{3}$

The second component exploits cross-industry variation in AD experience. Previous studies show that, due to the legal and institutional complexity of the $\mathrm{AD}$ process, industries with prior

measures implemented by the United States against China has dramatically increased during the last two decades, while the use of countervailing duties and safeguards is a more recent phenomenon. The use of AD protection is not limited to the United States. By the end of the 2000s, more than 93 countries worldwide had adopted AD laws (Vandenbussche and Zanardi, 2010).

${ }^{3}$ The argument that swing-state politics can shape US trade policy is also often heard in the media. An example is an article on the New York Times in 2004 on an AD case targeting imports of furniture from China. In this article, Congressman F. James Sensenbrenner Jr. from Wisconsin (a swing state in 2004) emphasized that "Wooden furniture is only a tiny part of China's $\$ 140$ billion of imports to the United States. But it is part of an overall rise in Chinese imports that has galvanized American industry groups and trade unions, and haunted politicians. If China continues to stonewall about this, it will be at their peril and they'll be caught in the cross-fire of a presidential election campaign (...) Unless China's huge trade deficit with the United States "can be addressed in the eyes of voters, it will be one of the three or four biggest issues in the campaign" (see "China's Furniture Boom Festers in U.S.", The New York Times, January 29, 2004). 
experience in $\mathrm{AD}$ cases face lower costs of filing and a higher probability of success in new cases (Blonigen and Park, 2004; Blonigen, 2006). Following this idea, I use information on AD petitions filed by US industries during the 1980s to construct a measure of an industry's ability to request protection.

I first apply my instrument to examine the impact of $\mathrm{AD}$ protection on imports. I show that US AD measures targeting China had a negative and significant effect on the growth rate of US imports from China. This result is robust to different sets of controls and fixed effects and to the possible trade diverting effects of antidumping. The estimates are sizable: my results indicate that a one-standard-deviation change in the average duty applied to Chinese firms decreases the annual growth rate of imports by 0.40 percentage points.

Then, I investigate the impact of trade protection on employment. I show that AD duties helped to shield workers from the "China syndrome," moderating the decline in manufacturing jobs. In terms of magnitude, my baseline estimates indicate that a one-standard-deviation change in the average duty increases the annual employment growth rate by 0.07 percentage points.

I show that trade policy can smooth the effects of trade shocks, shielding workers from import competition by focusing on WTO-compatible measures. It should be stressed, however, that these findings capture only the direct partial-equilibrium effects of $\mathrm{AD}$ on protected industries. They should thus not be interpreted as suggesting that protection against China is beneficial to the US economy as a whole. Indeed, access to low-cost goods from China has benefited US consumers (e.g., Amiti et al., 2017). Recent studies of the US-China trade war show that the increase in US tariffs against China generated sizable losses for US consumers and aggregate welfare (e.g., Amiti et al., 2019; Fajgelbaum et al., 2020). Protection has also negative effects along supply chains, hurting firms in downstream sectors (e.g., Erbahar and Zi, 2017; Flaaen and Pierce, 2019; Bown et al., 2020).

Understanding the impact of trade policy is key for the ongoing debate about the multilateral trading system's sustainability. President Trump and other politicians around the world have threatened to ignore the GATT/WTO, arguing that current multilateral trade rules do not allow them to protect their workers from unfair competition presented by China and other emerging economies. ${ }^{4}$ Showing that protectionist instruments allowed under multilateral rules can indeed be used to attenuate the effects of import competition could mitigate the criticisms about the inadequacy of the GATT/WTO. ${ }^{5}$

\footnotetext{
${ }^{4}$ On top of using $\mathrm{AD}$ duties and other protectionist measures allowed under multilateral trade rules, President Trump has relied on domestic legislation like Section 301 of the US Trade Act of 1974 to introduce unilateral measures against Chinese imports, triggering the ongoing US-China trade war. This started in January 2018 and has so far proceeded in four steps. The latest escalation has occurred in August 2019, when President Trump announced that he would nearly double the average US tariff on imports from China (see "The Trade War Is Suddenly Getting Worse" by Chad P. Bown).

${ }^{5}$ This idea is in line with Bagwell and Staiger (1990), who rationalize the use of contingent protectionist measures in trade agreements, showing that they can help to sustain a cooperative equilibrium with a low level of tariffs. Bown and Crowley (2013) provide evidence supporting the theory of Bagwell and Staiger (1990). They find that the
} 
The rest of the paper is organized as follows. Section 2 briefly discusses the related literature. Section 3 describes the institutional procedure for the introduction of $\mathrm{AD}$ duties in the United States. Section 4 presents the data used in the econometric analysis. Section 5 discusses the empirical methodology. Section 6 presents the empirical results. The last section concludes.

\section{Related Literature}

This paper builds on two main streams of literature. The first focuses on the effects of the rise of China as a trading power. In their seminal contribution, Autor et al. (2013) show that rising competition from Chinese imports had differential effects across US commuting zones. These are aggregates of counties, comprising well-defined local labor markets, that differ in their exposure to import competition as a result of regional variation in the importance of different manufacturing industries to local employment. This study is most closely related to Acemoglu et al. (2016), who aim to understand the puzzling slowdown of the US employment rate during the 2000 s, which overturned the realized gains during the so-called "Roaring Nineties" (Krueger and Solow, 2001). They estimate that 837,000 US manufacturing jobs were lost due to the direct effect of Chinese import penetration from 1991 to 2011. Pierce and Schott (2016) also attribute the drop in US manufacturing employment to rising imports from China, using an alternative identification strategy, based on the conferral of permanent most-favored-nation status to China upon entry into the WTO. ${ }^{6}$ Given this evidence of the negative effect of Chinese import penetration on US manufacturing employment, it is natural to investigate whether economic policy has been used to shield workers. This paper is the first to analyze the role of trade policy in smoothing the effects of increasing import penetration by Chinese products. The effectiveness of trade policy is not trivial because the possible gains from import protection could have been offset if trade were diverted from Chinese to third-country firms.

Second, my analysis is related to the literature on antidumping protection. ${ }^{7}$ Some studies aim to assess the effects of protection. Prusa (2001) provides evidence for the trade destruction effect of $\mathrm{AD}$ protection, showing that US AD measures decreased imports of targeted products by between $30 \%$ and 50\%. On the extensive margin, Besedes and Prusa (2017) find that US AD increases the probability of exit of foreign firms exiting the US market by more than $50 \%$. Lu et al. (2013)

probability of new $\mathrm{AD}$ measures is higher in sectors that have experienced a rise in imports, where import demand and export supply are relatively inelastic, and where import growth is less volatile.

6 There is also a growing literature that examines the effects of rising Chinese imports on other outcomes. Pierce and Schott (2020) study the effects of the China shock on mortality rates across US counties, while Colantone et al. (2019) consider its impact on mental health in the United Kingdom. Another stream of the literature focuses on political outcomes. Autor et al. (2020) show a positive impact of the "China syndrome" on political polarization in US, while Che et al. (2016) report an increase in turnout, Democratic vote shares, and probability of electing a Democratic candidate in the US counties most affected by the China shock. Autor et al. (2019) document a negative impact of the China shock on marriage stability in the United States.

${ }^{7}$ For a comprehensive review of the literature on AD, see Blonigen and Prusa (2016). 
and Felbermayr and Sandkamp (2020) combine granular product- and firm-level with differencein-differences estimations to examine the impact of $\mathrm{AD}$ on imports. Other studies consider the indirect effects of AD protection. Prusa (1997) and Konings et al. (2001) focus on trade diversion, showing that $\mathrm{AD}$ duties targeting one country can lead to an increase in imports from non-targeted countries. Bown and Crowley (2007) show that AD measures can give rise to trade deflection (i.e. an increase in exports from targeted countries to third countries) and trade depression (i.e. a decrease in exports from the targeted country to third countries). Antidumping can also have negative effects on aggregate trade, deterring imports from foreign firms that are not actually targeted. Vandenbussche and Zanardi (2010) estimate these "chilling effects" to account for about a $6 \%$ decrease in aggregate imports. The endogeneity of trade protection is one of the main challenges in the literature on antidumping. To the best of my knowledge, this paper is the first to propose an instrumental variable for $\mathrm{AD}$ duties to identify the causal effect of trade protection on industry outcomes.

\section{Antidumping in the United States}

The rationale behind $\mathrm{AD}$ laws is that they protect domestic producers against unfair trade practices by foreign firms. Under Article VI of the General Agreement on Tariffs and Trade and US trade laws, dumping is the sale of products by foreign producers at a price below the fair value.

The authorities impose an AD measure if two conditions are met: (1) the products are sold at "less than fair value" (LTFV), or "dumped", in the US market; and (2) the LTFV sales cause or threaten to cause material injury to the US import-competing industry. If these two conditions are met, an $\mathrm{AD}$ order is issued imposing a trade remedy that is a function of the amount by which the fair value exceeds the export price, as determined by sales to the United States.

In the United States, antidumping is administrated by two separate agencies: the US Department of Commerce (DOC) $)^{8}$ and the US International Trade Commission (ITC). The DOC is an integral part of the US Administration and its top positions are appointed by the President and confirmed by the Senate. ${ }^{9}$ The ITC is instead a bipartisan agency composed of six commissioners (three from each political party), who are nominated by the President and confirmed by the Senate.

An $\mathrm{AD}$ case starts with a petition filed to the DOC and the ITC, claiming injury caused by unfair import competition from a specific country. ${ }^{10} \mathrm{US}$ manufacturers or wholesalers, trade unions,

\footnotetext{
${ }^{8}$ Before 1980, the US Department of Treasury was in charge of dumping investigations. The US Congress decided to move this responsibility from the Treasury to the Department of Commerce, which was seen as more inclined to protect US business and workers than the Department of Treasury (Irwin, 2005).

${ }^{9}$ The President nominates the top positions in the department (Secretary, Deputy Secretary), as well as the key positions in charge of AD (e.g. Under Secretary for International Trade, Assistant Secretary for Market Access and Compliance). These appointees must be confirmed by the Senate. Several other lower-ranked positions involved in AD decisions (e.g. Deputy Assistant Secretary for Enforcement and Compliance) are usually politically appointed, but do not require confirmation by the Senate.

${ }^{10} \mathrm{An} \mathrm{AD}$ case may concern multiple AD petitions involving different countries exporting the same product. For
} 
and trade or business associations are all entitled to be petitioners, to the extent that they produce or sell a "like" product to the foreign article allegedly being dumped.

The DOC is in charge of the dumping investigation, which determines whether a product is imported at a price below the "fair value." The calculation of the dumping margin involves a considerable amount of complexity in defining what is the "fair value" for goods sold in the United States. According to the law, the DOC defines "fair value" as the foreign firm's price of the same good in its home country. However, this price is not always available, either because foreign firm's sales in its home market are negligible or because the home country is a non-market economy. ${ }^{11}$ If this is the case, the DOC can base the calculation of the "fair value" price on the exporting firm's price in third countries or on a constructed value based on the foreign firm's costs, when this information is provided. A product is declared to be dumped if the dumping margin is above a threshold established by the DOC.

The ITC is instead in charge of the material injury investigation. Under Section 201 of the Trade Act of 1974, the ITC "determines whether an article is being imported into the United States in such increased quantities as to be a substantial cause of serious injury, or the threat there-of, to the domestic industry producing an article like or directly competitive with the imported article." If the ITC finds that the relevant US industry has been materially injured, or threatened with material injury, as a result of the unfairly traded imports, an AD duty is introduced equal to the amount of dumping established by the DOC in the dumping investigation. ${ }^{12}$

\section{Empirical Strategy}

Studies that aim to evaluate the impact of protectionist measures on industry outcomes face serious identification concerns. In this section, I first discuss these concerns, before describing the instrument I propose to address them, and providing more details on the empirical methodology.

\subsection{Identification Concerns}

Antidumping duties and other protectionist measures can clearly impact the degree of import competition, which in turn can have effects on other variables (e.g. employment, productivity, innovation).

\footnotetext{
instance, in 2008, the AD case (USITC investigation n. 731-TA-1118 - 731-TA-1121) regarding "Light-Walled Rectangular Pipe and Tube" was targeting Chinese, Korean, Mexican, and Turkish products in the same AD case.

${ }^{11}$ In the case of China, Article 15 of its Protocol of Accession to the WTO allowed WTO members to treat China as a non-market economy (NME) until December 2016. Given the NME status, the DOC automatically relies on third surrogate countries to determine the dumping margin. This results in the imposition of larger duties on Chinese products. To this day, the United States has refused to grant the status of a market economy to China.

${ }^{12} \mathrm{An}$ AD investigation is divided into phases: a preliminary investigation in which the ITC conducts a preliminary phase injury investigation and the DOC determines if the imported products are being, or are likely to be, sold at less than the fair value. In the final phase, the ITC conducts the final injury investigation. For the rest of the paper, I will consider the final decision of the ITC to define the beginning of AD action.
} 
However, identifying the causal impact of trade protection on imports is challenging. As highlighted by Trefler (1993), trade policy and imports are simultaneously determined, leading to inconsistent estimates of their coefficients when using ordinary least squares (OLS) regressions. In the case of a standard linear regression model, the presence of a simultaneity bias leads to an upward bias in the coefficient of OLS if a rise in AD protection negatively affects imports, and an increase in imports increases the probability of receiving protection, meaning that OLS can overestimate the impact of $\mathrm{AD}$ protection on imports. ${ }^{13}$

A second identification concern is related to potential omitted variables, which might be correlated with both the degree of import penetration and the level of trade protection. Omitted variables could bias the OLS estimates upwards or downwards. For example, negative productivity shocks can lower domestic producers' competitiveness, leading to an increase in imports, and can be positively correlated to the level of tariffs (e.g. if declining industries are more likely to get protected). In this case, the OLS estimates would be biased downwards. Positive productivity shocks can instead boost domestic competitiveness and decrease imports, but might also be positively correlated to the level of tariffs (e.g. if the industry becomes more profitable and increases its ability to seek protection). In this case, the OLS estimates would be biased upwards. These simple examples highlight the difficulties of inferring the causal impact of protection on imports from simple OLS regressions.

Identification is even more challenging when studying the impact of trade policy on industry employment, which can be shaped by time-varying unobservable supply and demand shocks. The same set of variables can also affect $\mathrm{AD}$ protection, generating an omitted variable bias. Due to the the combined simultaneity and omitted variable biases, the effect of $\mathrm{AD}$ on industry-level outcomes cannot be consistently estimated by OLS.

\subsection{An Instrumental Variable for Antidumping Protection}

In the following section, I explain the rationale for the two components of my instrument, and for combining them in my identification strategy.

\subsubsection{Supply of Protection: The Swing Industry Variable}

The first component of my instrument measures the importance of industries in swing states and captures exogeneous variation in supply for protection.

Several studies have emphasized that trade policy in the United States is biased towards the interests of swing states. ${ }^{14}$ Muûls and Petropoulou (2013) find that industry's concentration in swing

\footnotetext{
${ }^{13}$ To demonstrate this, consider a simple two-equation structural model: Import $=\beta_{1} A D+\alpha_{1} z_{1}+\epsilon_{1}$ and $A D=$ $\beta_{2}$ Import $+\alpha_{2} z_{2}+\epsilon_{2}$. As shown in Wooldridge (2012), the asymptotic bias of OLS is given by the covariance between $A D$ and $\epsilon_{1}$. This is equal to $\operatorname{Cov}\left(A D, \epsilon_{1}\right)=\left[\beta_{2} /\left(1-\beta_{1} \beta_{2}\right)\right] \sigma^{2}$, with $\operatorname{Var}\left(\epsilon_{1}\right)=\sigma^{2}>0$. The covariance between $A D$ and $\epsilon_{1}$ is positive if $\beta_{1}<0$ and $\beta_{2}>0$.

${ }^{14}$ A striking example is the US Steel Tariff implemented by George W. Bush in 2002. As pointed out by Stephan
} 
states increases the probability of that industry receiving protection through a non-tariff barrier. Conconi et al. (2017) show that electoral incentives crucially affect the initiation of trade disputes. They find that US presidents are more likely to initiate a dispute against other WTO members concerning industries that are important in swing states. Ma and McLaren (2018) provide evidence of a swing state bias in US trade policy, showing that both MFN and pre-NAFTA discretionary Mexico-specific tariffs are higher for key industries in swing states. In a recent study, Fajgelbaum et al. (2020) analyze the impacts of the 2018 trade war on the US economy. They show that the so-called "Trump Tariffs" favored sectors located in electorally competitive counties.

Another stream of literature focuses on the political economy of US AD policy. Several studies focus on the role of the ITC. During the 1988-2016 period, the ITC ruled in favor of the petitioners in $67 \%$ of the cases. There is evidence that votes by ITC commissioners reflect the political interests of members of leading trade committees in Congress. ${ }^{15}$ Moore (1992) shows that petitions involving Senate Oversight Committee members' constituencies are systematically favored by the ITC. Hansen and Prusa (1997) find that industries linked to members of the House of Representatives Ways and Means Committee are more likely to receive protection. Aquilante (2018) finds that ITC commissioners are more likely to vote in line with the interests of the members of the Finance committee who belong to the same party that has appointed them. These studies suggest that the Finance and Ways and Means committees can influence AD decisions through different channels, e.g. appointment confirmations, budget allocation, and oversight hearings. ${ }^{16}$ Interestingly, congressmen from swing states are overrepresented in these powerful committees, ${ }^{17}$ which can be one of the reasons why $\mathrm{AD}$ protection is skewed in favor of key industries in these states.

The executive can also shape AD decisions. As discussed in Section 3, the President appoints key positions in the DOC, which is in charge of deciding whether a product has been "dumped" by foreign producers and setting the level of the duties. During 1988-2016, the DOC ruled in favor of the petitioners in $87 \%$ of the cases. The level of average duty of $49 \%$ (standard deviation 70 ) with the highest imposed duty of about $493 \%$. It has been argued that the DOC is politically captured. ${ }^{18}$ For example, in 2017 the DOC reversed its prior negative position on an AD case involving imports from Korea of oil country tubular goods, a type of steel product used in oil fields,

Bayers, the former UK Secretary of State for Trade and Commerce, in a letter to Pascal Lamy, this policy was "introduced for short-term political advantage ... to gain votes in key swing states like West Virginia, Ohio, Pennsylvania and Michigan where the steel industry is a major employer" (see Blair ally in poll threat to Bush (2003, November 17). The Guardian).

${ }^{15}$ The House Ways and Means Committee is in charge of US trade policy and has control over the budgets of public agencies (including the ITC). This power is shared with the Senate Finance Committee, which is also in charge of the confirmation of new ITC commissioners.

${ }^{16}$ Evidence for this influence can more easily be documented for the ITC (in which votes by individual commissioners are recorded) than for the DOC (for which only the final decision is made public).

${ }^{17}$ During the eight presidential elections in 1988-2016, swing states accounted for $21 \%$ of the number of US states on average. However, 33\% (36\%) of the new members of the Senate Finance (House Ways and Means) committee in a presidential term were from states classified as swing.

${ }^{18}$ A New York Times article denounced the "Commerce Department acting as judge and jury in AD cases" ("Politicized Trade Law: Helping Companies Avoid Market Forces", The New York Times, December 19, 1996). 
after Peter Navarro, Director of the National Trade Council, sent a "Recommendation for Action" letter requesting a minimum $36 \%$ import duty. ${ }^{19}$ There are also examples of swing-state politics affecting $\mathrm{AD}$ decisions by the DOC. ${ }^{20}$

The broad idea behind the first component of my instrument is that the President and members of Congress have incentives to implement policies that increase their probability of winning votes in battleground states. In line with several studies (e.g. Conconi et al., 2017; Ma and McLaren, 2018; Fajgelbaum et al., 2020), we use information on vote shares in previous presidential elections to identify swing states. In particular, I follow a procedure similar to Conconi et al. (2017):

1. For each year and in a given presidential term, I collect information on the vote shares of the two major parties in the previous presidential elections.

2. I define the dummy variable $S w i n g_{s, t}$, which is equal to 1 if state $s$ is electorally competitive in year $t$, i.e. if the difference in the vote shares is less than $5 \%$.

Figure A-4 in the Appendix illustrates which states are classified as swing in the six presidential elections from 1988 to 2008 based on the above definition of swing states. Notice that both the number and identity of the swing states changes in each election. ${ }^{21}$

I then define the measure of an industry's importance in swing states as the ratio of the total number of workers employed in industry $i$ in all swing states $s$ in year $t$, over the total number of workers in tradable sectors in swing states $s$ during year $t$ :

$$
\text { Swing Industry } \text { I }_{, t}=100 \times \frac{\sum_{s} L_{s, i}^{1988} \times \text { Swing }_{s, t}}{\sum_{s} \sum_{i} L_{s, i}^{1988} \times \text { Swing }_{s, t}},
$$

\footnotetext{
${ }^{19}$ See US Court of International Trade, Consol. Court No. 17-00091.

${ }^{20}$ For instance, close to the 2012 presidential election, the DOC declared its decision to end an sixteenyear-old agreement with the Mexican government about exports of tomatoes. This led to the reopening of $\mathrm{AD}$ investigation by the DOC, just before the re-election of President Obama. Production of tomatoes is very concentrated in swing states such as Florida. Gary Clyde Hufbauer, former deputy assistant secretary for international trade and investment policy at the US Department of Treasury, declared that "this a debate being fought out in the context of this presidential election, and Florida is one of those swing states" (see "Ammunition for a Trade War Between US and Mexico", The New York Times, September 27, 2012). Debaere (2009) focuses on an AD case filed by the Southern Shrimp Alliance (SSA) in 2004. The case led to the imposition of $\mathrm{AD}$ duties of up to $113 \%$ on shrimp imports from several countries (China, Thailand, Vietnam, India, Brazil, and Ecuador). He notes that "2004 was an election year in the United States and that some of the eight SSA states were expected to be political battlegrounds," which helps explain why the duties were introduced, notwithstanding strong opposition by US seafood distributors, retailers, restaurateurs, and other businesses involved in shrimp processing and marketing.

${ }^{21}$ The swing states were: in 1988, California, Illinois, Maryland, Missouri, New Mexico, New York, Oregon, Pennsylvania, Vermont, Washington, West Virginia, and Wisconsin; in 1992, Arizona, Colorado, Florida, Georgia, Kentucky, Louisiana, Montana, Nevada, New Hampshire, New Jersey, North Carolina, Ohio, South Dakota, Tennessee, Texas, Virginia, and Wisconsin; in 1996, Arizona, Colorado, Georgia, Kentucky, Montana, Nevada, North Carolina, South Dakota, Tennessee, Texas, and Virginia; in 2000, Florida, Iowa, Minnesota, Missouri, Nevada, New Hampshire, New Mexico, Ohio, Oregon, Pennsylvania, Tennessee, and Wisconsin; in 2004, Colorado, Iowa, Michigan, Minnesota, Nevada, New Hampshire, New Mexico, Ohio, Oregon, Pennsylvania, and Wisconsin; in 2008, Florida, Indiana, Missouri, Montana, North Carolina, and Ohio; in 2012, Florida, North Carolina, Ohio, and Virginia.
} 
where $L_{s, i}^{1988}$ is the number of workers in industry $i$ in state $s$ in 1988. The industry's employment shares are fixed at 1988 levels (before the China shock) to satisfy the exclusion restriction. It should be stressed, however, that the geographical distribution of industries across states is very stable over time, so using employment shares for later years would yield very similar results. ${ }^{22}$

The variable Swing Industry $_{i, t}$ is meant to capture exogenous variation in the supply for AD protection due to the changing political importance of different industries. The 1988 employment shares pin down the importance of different industries across US states, while changes in the identity of swing states capture variation in the political importance of different states across electoral terms. Industries that are more politically important should get more protection. ${ }^{23}$

My identification strategy relies on the assumption that the identity of swing states is exogenous to trade policy. This is the case if there is no reverse causality between my instrument and trade protection. In other words, the extent of state-level $\mathrm{AD}$ protection during a presidential term does not affect which states are classified as swing at the end of that term (i.e. for which states the difference in vote shares between the Democratic and Republican candidates is less than 5\%).

To verify this, I have constructed a measure of $\mathrm{AD}$ protection at the state level:

$$
A D_{s, t}=100 \times \sum_{i} \alpha_{i, s} \tau_{i, t}
$$

where $\tau_{i, t}$ is the $\mathrm{AD}$ duty applied in industry $i$ in year $t$ and $\alpha_{i, s}$ is the share of employment in industry $i$ in state $s$ in 1988. I have then regressed the probability that a state is classified as swing at the end of a term against the variable $\Delta A D_{s, t}$. The coefficient of this variable is insignificant, confirming that trade policy does not affect the identity of swing states (see column (1) of Table A-1 in the Appendix). ${ }^{24}$

As a final remark, the discussion above suggests that the US President and members of his party will try to influence AD decisions to grant protection to key industries in swing states, so as to increase their vote shares in these states in the next presidential election. To verify this, I have examined whether changes in state-level AD protection during a presidential term $\left(\Delta A D_{s, t}\right)$ affect state-level changes in the vote share of the incumbent president's party in the presidential election at the end of that term ( $\Delta$ Vote $\left._{\text {Share }}, t\right)$. The results are reported in column (2) of Table A-1 in the Appendix. The coefficient of the variable $\Delta A D_{s, t}$ is positive and significant, confirming that an increase in $\mathrm{AD}$ protection has a positive and significant effect on the vote share of the incumbent

\footnotetext{
${ }^{22}$ This can be seen looking at Figure A-5, in which we have plotted state-level employment shares by SIC4 industry in 1988 and 2011, using data from Acemoglu et al. (2016). The figure shows that variation in the location of industries across US states is very limited over time (the correlation between the shares in the two years is 0.96).

${ }^{23}$ As an example, if we compare AD duties targeted against Chinese imports of steel products (SIC3312), the highest average level (264 percent) is found in the first term of President Obama, during which Ohio, a major producer of steel, was one of the six states classified as swing. Based on 1988 statistics, Ohio accounts for 29.75 percent of US employment in industry SIC3312, the largest share of all US states. Within Ohio, steel is the second-largest industry in terms of manufacturing employment, accounting for around 50,000 jobs.

${ }^{24}$ All specifications in Table A-1 include state and year fixed effects and cluster standard errors at the state level.
} 
president's party. In terms of magnitude, a one-standard-deviation change in $\Delta A D_{s, t}$ increases the vote share of the President's party by 0.31 percentage points. This effect is sizable since it explains $9 \%$ of the average change in Vote Share $_{s, t}$ and $13 \%$ of the vote margin in swing states. ${ }^{25}$

\subsubsection{Demand of Protection: The Experience Variable}

The second component of my instrument measures the experience of industries at filing AD petitions and captures exogeneous variation in demand for protection.

As mentioned in Section 3, the AD process involves a high degree of legal and institutional complexity. Experience in the relevant legal and institutional procedures can thus decrease the costs of future filings, and increases the likelihood of successful outcomes and the magnitude of the applied duty. Indeed, several studies show how prior experience in AD filings helps to explain future success in getting AD protection (Blonigen and Park, 2004; Blonigen, 2006). The experience acquired by an industry petitioning for $\mathrm{AD}$ prior to the China shock can thus provide exogenous cross-industry variation in demand for $\mathrm{AD}$ protection.

Following this idea, I define the variable:

$$
\text { Experience }_{i}=\sum_{t=1980}^{1987} \text { Petition }_{i, t},
$$

which is the number of AD petitions filed by industry $i$ for the years before the China shock, during 1980-1987. To satisfy the exclusion restriction, I exclude petitions that led to AD measures in force during 1988-2016 and petitions that targeted Chinese products.

The 1980s are particularly interesting because of the steep increase in the number of AD petitions filed (418, compared to 280 in the previous decade). Irwin $(2005,2017)$ argues that this increase is due to various legal and institutional changes in $\mathrm{AD}$ proceedings that made it easier to file for $\mathrm{AD}$ protection. Thus, during this decade many industries were able to accumulate experience in the AD process. This was particularly the case for those sectors that were highly exposed to competition from Japan (e.g. automotive, steel, electronics), which at the time was by far the largest exporter to the US, accounting for around $20 \%$ of its imports. ${ }^{26}$ Interestingly, the textile and apparel industry was subject to strong import competition in the 1980s, but did not acquire much AD experience, partly due to the fact that the sector was already protected by the Multi-Fiber Arrangement (Irwin, 2017).

\footnotetext{
${ }^{25}$ The standard deviation of $\Delta A D_{s, t}$ is 10.37 , the average change in Vote Share Vo $_{s}$ is -3.31 , the average margin between the democratic and republican party in presidential elections is $2.38 \%$.

${ }^{26}$ The corresponding share for China was less than $2 \%$. Around $21 \%$ of the AD petitions in the 1980s targeted Japanese firms (the share of AD petitions targeting Chinese firms was around $8 \%$ ).
} 


\subsubsection{Combining Supply and Demand for Protection}

My instrument for AD protection is defined as follows:

$$
I V_{i, t}=\text { Swing Industry }_{i, t} \times \text { Experience }_{i},
$$

where Swing Industry I $_{t}$ captures exogeneous cross-industry variation in supply for protection,

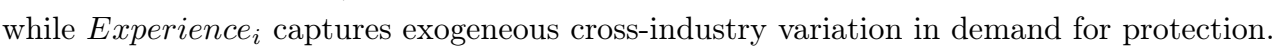

The logic of my identification strategy is that the most protected industries during a given presidential term should be those that are more important in battleground states (as captured by Swing Industry ${ }_{i, t}$ ) and that can exploit this political advantage because of their long-term knowledge of the complex institutional pathways to AD protection (as measured by Experience ${ }_{i}$ ). Combining the two components generates a stronger instrument, allowing to better predict $\mathrm{AD}$ duties.

Tables A-3 and A-4 in the Appendix provide lists of the top-10 SIC 4 industries based on Swing Industry $_{i, t}$ and Experience ${ }_{i}$, with the corresponding level of $\mathrm{AD}$ protection. Notice that industries appearing in both lists have high levels of protection compared to industries appearing in only one of the two. For example, sectors "Motor vehicle parts and accessories" (SIC 3714) and "Blast furnaces and steel mills" (SIC 3312) - which are both politically important (respectively ranked as number 4 and 7 based on Swing Industry $_{i, t}$ ) and both have experience at filing for AD protection (respectively ranked as number 2 and 1 based on Experience $_{i}$ ) - receive a high level of protection (the average $\mathrm{AD}$ duties on these industries are respectively $142.9 \%$ and $81.61 \%$ ). By contrast, an industry like "Search and navigation equipment" (SIC 3812) - which appears in the top-10 list in terms of political importance, but not experience - and an industry like "Industrial trucks and tractors" (SIC 3537) - which appears in the top-10 list in terms of experience, but not political importance - are not protected.

My identification strategy helps to deal with the endogeneity concerns illustrated in Section 5.1. It deals with the simultaneity concerns emphasized by Trefler (1993): changes in my instrument always precede changes in $\mathrm{AD}$ duties, given that the employment shares and the industry experience are fixed at the beginning of the sample, and the identity of the swing states is fixed and the beginning of each term.

The strategy also allows me to deal with omitted variable concerns. The number and identify of swing states changes after each presidential election. Combined with the historical geographical distribution of sectors across states, this generates exogenous variation in the political importance of an industry. One might worry that industry employment in swing states may be affected by other federal policies (e.g. transfers) that could be used to favor these industries. However, my instrument is the interaction between Swing Industry I $_{i, t}$ and Experience $_{i}$, and thus only exploits variation in the political importance of an industry that is relevant for AD policy, satisfying the 
exclusion restriction.

\subsection{Estimating the Impact of Antidumping on Imports and Employment}

In this subsection, I present the econometric models used in the empirical analysis.

In the first part, I use my instrument to identify the impact of $\mathrm{AD}$ on US imports. This result is key to understanding the impact of trade policy in shielding workers from the China syndrome, given that the only channel through which $\mathrm{AD}$ can affect the labor market is a decrease in imports. For this purpose, I estimate the following equation by two-stage least squares (2SLS):

$$
\Delta \text { Imports }_{i, t}=\beta_{0}+\beta_{1} \Delta A D_{i, t}+\delta_{j(i), t}+\varepsilon_{i, t} .
$$

Each industry $i$ is defined at the 4-digit SIC level. The dependent variable is 100 times the annualized log change in US imports from China in industry $i$ at time $t$. Given that my instrument varies at the president term level, this is also the time dimension $t$ of the panel.

The key variable of interest is $\Delta A D_{i, t}$, which captures the annualized change in the level of US AD protection against Chinese firms during a presidential term $t$. I measure AD protection by the average $\mathrm{AD}$ duty in industry $i\left(\right.$ Duty $\left._{i, t}\right)$. The endogenous variable $\Delta A D_{i, t}$ is instrumented using $\Delta I V_{i, t}$, the change in the proposed instrument in term $t$ relative to $t-1$. To account for time-varying industry trends, I also include industry-time fixed effects $\left(\delta_{j(i), t}\right)$, where industry $j$ is defined at the 3-digit SIC level. In all the specifications, standard errors are clustered at the 3-digit SIC level. ${ }^{27}$

Crucially, to induce a positive effect on employment, the decline in US imports due to AD measures against China must have outweighed a possible increase in US imports from non-targeted countries. To verify this, I estimate the following:

$$
\Delta \text { Imports }_{i, c, t}=\beta_{0}+\beta_{1} A D_{i, t}+\beta_{2} A D_{i, t} \times C h i n a_{c}+\mu_{j(i), c, t}+\varepsilon_{i, c, t} .
$$

This econometric model allows me to examine the effects of US AD measures against China on US imports from China and other countries. The dependent variable is defined as 100 times the annual change in the $\log$ of US imports from country $c$ in sector $i$ over period $t, C h i n a_{c}$ is a dummy variable identifying imports from China. The industry-country-time fixed effects $\left(\mu_{j(i), c, t}\right)$ allow me to control for time-varying shocks in an industry $j$ for the exporting country $c$. In all the specifications, standard errors are clustered to the 3-digit SIC level.

\footnotetext{
${ }^{27}$ Results are robust to clustering standard errors at the 4-digit SIC level.
} 
To estimate these coefficients, I first restrict my analysis to the set of countries that are among the top 15 exporters to the US (excluding China) in at least one HS6 product covered by AD protection against China from 1992 to 2012. This allows me to exclude all the small countries that are not relevant competitors with Chinese products in the US, reducing the level of noise. ${ }^{28}$ Second, I exclude imports from sectors and countries named in an $\mathrm{AD}$ case including Chinese products. Indeed, AD cases targeting Chinese imports can also involve imports from other countries. Including those countries would artificially depress imports from countries other than China, making it harder to identify the trade-diverting effect of $\mathrm{AD}$. The coefficient $\beta_{1}$ captures possible tradediversion effects (i.e. an increase in imports from non-targeted countries). The sum of $\beta_{1}$ and $\beta_{2}$ captures instead destruction of trade with with China.

As a robustness check, I include imports from any country named in a AD case against China and estimate the following model:

$$
\begin{aligned}
\Delta \text { Imports }_{i, c, t}= & \beta_{0}+\beta_{1} \Delta A D_{i, t}+\beta_{2} \Delta A D_{i, t} \times \text { China }_{c}+\beta_{3} \Delta A D_{i, t} \times \text { Named }_{i, c, t} \\
& +\beta_{4} \text { Named }_{i, c, t}+\mu_{j(i), c, t}+\varepsilon_{i, c, t},
\end{aligned}
$$

where Named $_{i, c, t}$ is a dummy variable equal to 1 if imports of industry $i$ from country $c$ are subject to $\mathrm{AD}$ duties in year $t$, as a result of an $\mathrm{AD}$ case involving China.

In the second part of the empirical analysis, I examine the impact of $\mathrm{AD}$ on employment.

$$
\Delta L_{i, t}=\beta_{0}+\beta_{1} \Delta A D_{i, t}+\delta_{j(i), t}+\varepsilon_{i, t}
$$

Each industry $i$ is defined at the 4-digit SIC level. The dependent variable is 100 times the annualized log change in US employment in industry $i$ during presidential term $t . \Delta A D_{i, t}$ is the annualized change in the level of US AD protection against Chinese firms in presidential term $t$. As in equation 5 , I instrument the average $\mathrm{AD}$ duty in industry $i$ using $\Delta I V_{i, t}$ and I include industry-time fixed effects to account for time-varying industry trends.

\section{$5 \quad$ Data and Variables}

The data used in the empirical analysis is collected from four data sources. The first source of information is the World Bank's Temporary Trade Barriers Database (TTBD). The TTBD (Bown, 2014) provides detailed information on AD cases for more than thirty countries in the world. For each case, it includes the date of initiation of the investigation, the date of imposition of a final

\footnotetext{
${ }^{28}$ The sample includes 104 countries. The results of Table 2 continue to hold if I consider all WTO members (without limiting the sample to the top 15 exporters to the US) or use a longer time period (from 1991 to 2016). The results of these robustness checks are available upon request.
} 
AD measure (if approved), the product's country of origin, and the description of the product under investigation with corresponding Harmonized System (HS) codes. For the US, product data are extremely detailed with around $97.5 \%$ of petitions identified at the 6-digit Harmonized Tariff Schedule (HTS) level (or at 5-digit Tariff Schedule of the United States Annotated for years before 1989). Thanks to this granularity, it is possible to link each investigation with the corresponding 4-digit Standard Industrial Classification (SIC) code. Mapping each AD action to a corresponding SIC code allows me to investigate the impact of AD on industry-level outcomes.

The matching of the HS to the SIC classification is executed using the following procedure:

1. Each 6-digit HS code is matched with one or more 4-digit SIC codes using the crosswalk file by Autor et al. (2013). Around $94 \%$ of the AD cases are mapped using this correspondence table. $^{29}$ To map each HS6 product to only one industry, I assign an HS6 code to the industry which represents the largest share of that product's US imports. This means that each HS6 product is mapped to only one 4-digit SIC industry. However, each AD case may involve multiple HS6 products and thus be linked to more than one SIC4 code. ${ }^{30}$

2. The remaining "unmatched" HS6 products are mapped to a SIC code by aggregating up the information of the crosswalk file at HS4. In this case, a product is matched to an industry if its correspondent HS4 family maps to only one SIC4 industry. All the unmatched HS6 products are manually matched to a corresponding SIC4 industry by directly retrieving information about the corresponding AD case from the ITC case descriptions.

Between 1988 and 2016, the US initiated 185 cases in which China was one of the countries accused of dumping (corresponding to $33.7 \%$ of the total new AD cases). As a result of those cases, the US imposed 137 measures on Chinese products ( $74 \%$ affirmative). The investigations cover a large variety of products, mainly in the manufacturing sector.

In my empirical analysis, I use five different metrics for AD protection, defined at the SIC4 level:

Duty $_{i, t}$ : this is the average AD duty applied against Chinese firms in sector $i$ in year $t$;

Dummy $y_{i, t}$ : this is a dummy equal to 1 if there is at least one AD measure in force targeting Chinese firms in sector $i$ and in year $t$;

Count of Products Pr, $_{\text {: }}$ this is the number of products (at 6-digit HS level) covered by at least one AD measure in force targeting Chinese firms in sector $i$ and in year $t$;

\footnotetext{
${ }^{29}$ For the years up to 1988 , descriptions of products were provided according to the Tariff Schedule of the United States Annotated (TSUSA) classification. Therefore, for AD cases before 1988, I match each TSUSA code with a corresponding HS code using the correspondence table provided by Feenstra (1996). It is possible to download the crosswalk file to concord TSUSA codes to HS codes on the UC Davis - Centre for International Data website: http://cid.econ.ucdavis.edu/usix.html.

${ }^{30}$ The products' HS codes are harmonized over time to the HS1992 revision using the concordance tables by the United Nations Statistics Division.
} 
Product Coverage $_{i, t}$ : this is the share of products (at 6-digit HS level) covered by at least one $\mathrm{AD}$ measure in force targeting Chinese firms over the total number of products in sector $i$ in year $t$;

Import Coverage $_{i, t}$ : this is the share of imports covered by at least one $\mathrm{AD}$ measure targeting Chinese firms over the total value of imports in sector $i$ in year $t$.

In the empirical analysis, Duty $i_{i, t}$ will be used as the main measure of AD protection, while the other four measures will be used in robustness checks.

Table A-2 in the Appendix presents some descriptive statistics of the five AD measures during the period 1988-2016. The statistics are for the 2-digit SIC manufacturing sectors. ${ }^{31}$

The sector with the higher AD duty is primary metal industries (SIC2 22), with an average duty of $43.39 \%$ and a product coverage of $4.43 \%$. This sector represents historically protected industries such as producers of steel and aluminum. Other industries with a high level of protection are chemicals and allied products (average duty of $18.68 \%$ ), paper and allied products (average duty of $36.64 \%$ ), fabricated metal products (average duty of $22.34 \%$ ), and transportation equipment (average duty of $19.28 \%$ ).

To analyze the effects of $\mathrm{AD}$ protection on trade flows, I use trade data from the United Nations' (UN) Comtrade Database. This provides information on bilateral trade flows for 6-digit HS codes. All imports are expressed in real 2007 dollars. To map trade flow in HS to a 4-digit SIC industry, I use the crosswalk file used in Autor et al. (2013). When an HS6 product is matched to multiple 4-digit SIC industries, the associated value of imports is included in the imports of the matched industry weighted by the product's share of US imports in that specific 4-digit SIC industry. Furthermore, the NBER - Center for Economic Studies (CES) Database provides a rich set of information on industry performance from 1971 to 2011 that will later be useful for the construction of industry-level controls.

The descriptive statistics of the key variables used in my empirical analysis are presented in Table A-5 in the Appendix.

\section{Empirical Results}

\subsection{Effect of Antidumping on Imports}

The main goal of this paper is to show that US AD measures against China had a positive impact on employment in protected industries. For this effect to be at work, these measures must have had a negative impact on US imports of targeted Chinese products. This is verified by estimating the

\footnotetext{
${ }^{31}$ The values in Table A-2 are calculated by averaging the metrics of AD protection across all the 4-digit SIC sectors within each 2-digit SIC sector during the sample period 1988-2016. Then, this average includes zeros in the database.
} 
model presented in equation (5). My benchmark is the period from 1992 to 2012 consistent with the time span used in previous studies on the China syndrome. ${ }^{32}$

Table 1: Effect of AD on imports from China

\begin{tabular}{lcccc}
\hline \hline & $(1)$ & $(2)$ & $(3)$ & $(4)$ \\
& Duty & & \\
& $-0.09^{* *}$ & Duty & & Duty \\
& $(0.05)$ & -0.06 & $-0.34^{* * *}$ & $-0.24^{* *}$ \\
\hline$A D_{i, t}$ & Yes & $(0.05)$ & $(0.13)$ & $(0.10)$ \\
\hline Industry $\times$ Term FE & Yes & Yes & Yes \\
Span & $1992-2012$ & $1992-2016$ & $1992-2012$ & $1992-2016$ \\
Method & OLS & OLS & 2 SLS & 2 SLS \\
Adjusted R2 & 0.29 & 0.31 & & \\
F-statistic & & & 36.49 & 83.54 \\
Observations & 1,618 & 1,948 & 1,618 & 1,948 \\
\hline \hline
\end{tabular}

Notes: The dependent variable $\Delta$ Imports $_{i, t}$ is the annual growth rate of US imports from China for industry $i$ defined as the $\log$ difference during a presidential term $t$. Estimates of the coefficient $\beta_{1}$ of equation (5) are provided for AD defined as the average AD duty in $t$. Industry $\times$ Term fixed effects are defined at 3-digit SIC level. Standard errors in parentheses are clustered at the 3-digit SIC level. Significance levels: ${ }^{*} p<.10,{ }^{* *} p<.05,{ }^{* * *} p<.01$.

The results are shown in Table 1. In column (1), I analyze the OLS estimates for my benchmark period. As expected, the coefficient is negative. In column (3), I show the 2SLS estimates: a $1 \%$ increase in the average duty decreases imports from China by 0.34 percentage points per year and the coefficient is significant at $1 \%$. Comparing columns (1) and (3), notice that the estimated effect is larger for the 2SLS estimates. This suggests that OLS might underestimate the effect of trade policy. In columns (2) and (4), as robustness check, I analyze the effect of AD on imports by including the years between 1992 and 2016. In column (4), the 2SLS estimates suggest that a $1 \%$ increase in the average duty decreases imports from China by 0.24 percentage points per year and the coefficient is significant at 5\%. Again, if I compare the OLS estimates with those from 2SLS, I obtain a larger estimate when I deal with the endogeneity of trade policy.

To understand the magnitude of the effect, I look at the percentage change of the average import growth rate induced by a one-standard-deviation increase in $\Delta A D_{i, t}$. The baseline estimate in column (3) of Table 1 implies that a one-standard-deviation increase in the average AD duty decreases the annual growth rate of imports by 0.40 percentage points. ${ }^{33}$ The estimates in column

\footnotetext{
${ }^{32}$ E.g., Acemoglu et al. (2016) consider the period from 1991 to 2011 in their study analyzing the effects of the China shock.

${ }^{33}$ This number is obtained by multiplying the estimated coefficient for $\Delta A D_{i, t}(-0.34)$ by the standard deviation of the predicted $\triangle A D_{i, t}(1.19)$.
} 
(4) indicate that a one-standard-deviation increase in $\Delta A D_{i, t}$ decreases the annual growth rate of imports by 0.25 percentage points.

At the bottom of Table 1, I report the F-statistics to verify the predictive power of my proposed instrument. In all specifications, they are always above 10 , so I reject the hypothesis that $I V_{i, t}$ is a weak instrument to measure AD protection. In Table A-6 of the Appendix, I show the full results of the first stage for the 2SLS regressions presented above. As expected, the coefficient of $I V_{i, t}$ is positive and significant in all specifications.

In Table A-7 of the Appendix, I show as a robustness check the results of the regressions when the dependent variable $\Delta$ Import $_{i, t}$ is calculated including observations where imports from China are zeros in the UN Comtrade database. In this case, I retain the sectors in which $\Delta$ Imports $_{i, t}$ is greater than zero in at least one year between the first and the final year of a presidential term. To account for the presence of zeros in industry imports from China, $\Delta$ Imports $_{i, t}$ is defined as the difference in the log of one plus the US imports from China during a presidential term. The results are not statistically different when zeros are included because the key variable $A D_{i, t}$ is always negative and significant.

In Table A-8, I show an additional set of robustness checks where I consider the following alternative measures of $\mathrm{AD}$ protection: a dummy if industry $i$ is protected by at least an $\mathrm{AD}$ measure in $t$ (Dummy); the number of products (defined at HS6) protected by at least one AD measure in industry $i$ in $t$ (Count of Products); the ratio of the value of imports protected by at least one $\mathrm{AD}$ measure over the total value of imports of industry $i$ in $t$ (Import Coverage); and the ratio of the number of protected products by at least one $\mathrm{AD}$ measure over the total number of products imported for industry $i$ in $t$ (Product Coverage).

In all my specifications, the presence of industry-term fixed effects allows me to control for broad time-varying industry trends. However, to verify whether my results are robust to the presence of industry trends at the 4-digit SIC level, I control for all the industry-level variables used by Acemoglu et al. (2016), all defined at the 4-digit SIC level: the log of average wage in 1991, the ratio of capital on value added in 1991, the ratio of production workers over total employment in 1991, computer investment as a share of total investment in 1990, and high-tech investment as a share of total investment in 1990. These variables are meant to control for potential exposure to technological changes in capital-, computer-, and skill-intensive sectors.

Moreover, I include pre-trend controls: the logarithm of average wage in 1976-1991, and the logarithm of the industry's average share of total employment. Pre-trend controls are included for two reasons. The first is that many US industries had already been declining since the $1980 \mathrm{~s}$, so there is a need to control for secular employment trends. Second, the estimated effect of $A D_{i, t}$ is cleaned from the effects of any other policy designed to support declining industries. Lastly, including pretrend controls mitigates the concerns about the possibility of the variable Experience $_{i}$ capturing declining industries. In Table A-10, I show that my results are robust to the inclusion of both 
production and pre-trend controls. The variable $\Delta A D_{i, t}$ is always negative and significant at $1 \%$.

In another robustness check, I get data on countervailing duties and safeguards from the TTBD to get the full set of temporary trade barriers (TTBs). Table A-9 of the Appendix shows that, in all the specifications, AD has a negative and significant effect on US imports from China.

Table 2: Effect of $\mathrm{AD}$ on imports from China: trade destruction vs trade diversion

\begin{tabular}{lcccc}
\hline \hline & $(1)$ & $(2)$ & $(3)$ & $(4)$ \\
& Duty $_{i, t}$ & Duty $_{i, t}$ & Duty & Dut \\
& -0.16 & -0.08 & -0.05 & 0.02 \\
\hline$A D_{i, t}$ & $(0.10)$ & $(0.06)$ & $(0.06)$ & $(0.05)$ \\
& & & & \\
$\Delta A D_{i, t} \times$ China $_{c}$ & $-0.18^{* * *}$ & $-0.16^{* * *}$ & $-0.27^{* * *}$ & $-0.25^{* * *}$ \\
& $(0.04)$ & $(0.05)$ & $(0.04)$ & $(0.05)$ \\
$\Delta A D_{i, t} \times$ Named $_{i, c, t}$ & & & & $-0.36^{* * *}$ \\
& & & $(0.13)$ & $(0.11)$ \\
\hline Industry $\times$ Term $\times$ Country FE & Yes & Yes & Yes & Yes \\
Span & $1992-2012$ & $1992-2016$ & $1992-2012$ & $1992-2016$ \\
Method & 2 SLS & 2 SLS & 2 SLS & 2 SLS \\
F-statistic & 7.99 & 16.63 & 34.92 & 45.52 \\
Observations & 78,974 & 97,667 & 79,849 & 98,685 \\
\hline \hline
\end{tabular}

Notes: The dependent variable $\Delta$ Imports $_{i, c, t}$ is the annual growth rate of US imports from country $c$ for industry $i$ defined as the $\log$ difference during a presidential term $t$. Estimates of the coefficients $\beta_{1}, \beta_{2}$, and $\beta_{3}$ of equations (6) and (7) are provided for AD defined as the average AD duty in $t$. Industry $\times$ Term fixed effects are included in all the specifications. Standard errors in parentheses are clustered at the 3 -digit SIC level. Significance levels: * $p<.10,{ }^{* *} p<.05,{ }^{* * *} p<.01$.

In the second part of this subsection, I verify that the effects on Chinese imports are not offset by an increase in imports from other trade partners. This is an important mechanism which reinforces the result that $\mathrm{AD}$ shields workers from the China syndrome. Therefore, I use the model described in equations (6) and (7) to test the magnitude of the trade destruction associated with $\mathrm{AD}$ with respect to the trade-diversion effect. In equation (6), the coefficient $\beta_{1}$ captures possible trade diversion effects (i.e. an increase in imports from non-targeted countries). The sum of $\beta_{1}$ and $\beta_{2}$ captures instead trade destruction with China. In equation (7), there is an additional coefficient $\beta_{3}$ that captures the effect of $\mathrm{AD}$ cases targeting Chinese firms on other countries named in the same case. For columns (3) and (4), the trade destruction effect of AD measures is given by the sum of $\beta_{1}, \beta_{2}$, and $\beta_{3}$. 
The results are shown in Table 2. The coefficients are estimated with 2SLS. Columns (1) and (2) show the estimates of equation (6). The sum of $\beta_{1}$ and $\beta_{2}$ is negative and significant, confirming that $\mathrm{AD}$ measures against China led to a contraction in targeted Chinese imports. There is no statistical evidence of trade diversion: although the sign of $\beta_{1}$ is always positive as expected, the coefficient is never significant. Results are robust when I include the imports from other named countries as shown in columns (3) and (4).

To sum up, the results reported in this subsection show that US protectionist measures led to a decline in US imports from China, which was not compensated by an increase in imports from non-targeted countries.

\subsection{Effect of Antidumping on Employment}

In this section, I apply my instrument to estimate the effect of $\mathrm{AD}$ actions on employment, presenting the results of the two-stage least squares (2SLS) estimation of equation (8).

Table 3: Effect of AD on employment

\begin{tabular}{lcccc}
\hline \hline & $(1)$ & $(2)$ & $(3)$ & $(4)$ \\
& Duty $_{i, t}$ & Duty $_{i, t}$ & Duty $_{i, t}$ & Duty $_{i, t}$ \\
\hline$\Delta A D_{i, t}$ & $0.02^{*}$ & $0.02^{*}$ & $0.06^{* * *}$ & $0.06^{* * *}$ \\
& $(0.01)$ & $(0.01)$ & $(0.01)$ & $(0.01)$ \\
\hline Industry $\times$ Term FE & Yes & Yes & Yes & Yes \\
Span & $1992-2012$ & $1988-2016$ & $1992-2012$ & $1988-2016$ \\
Method & OLS & OLS & 2 SLS & 2SLS \\
Adjusted R2 & 0.42 & 0.42 & & \\
F-statistic & & & 36.63 & 110.69 \\
Observations & 1,689 & 2,364 & 1,689 & 2,364 \\
\hline \hline
\end{tabular}

Notes: The dependent variable $\Delta L_{i, t}$ is the annual growth rate of US employment im industry $i$ defined as the log difference during a period $t$. Estimates of the coefficient $\beta_{1}$ of equation (8) are provided for AD defined as the average AD duty in $t$. Industry $\times$ Term fixed effects are included in all the specifications. Standard errors in parentheses are clustered at the 3 -digit SIC level. Significance levels: ${ }^{*} p<.10,{ }^{* *} p<.05,{ }^{* * *} p<.01$.

The estimated effects of $\mathrm{AD}$ for the econometric model described in (8) are provided in Table 3. Notice that the F-statistics reported at the bottom of the table are always above 10, confirming the strength of the instrument. ${ }^{34}$ In my benchmark specification in column (3), I show that a $1 \%$ increase of the average duty in sector $i$ in period $t$ increases the annual growth rate of employment by 0.06 percentage points. These estimates are equivalent to those presented in column (4) when I consider the enlarged sample (1988-2016). In all the specifications estimated with 2SLS, the coefficients of $A D_{i, t}$ are statistically significant at the $1 \%$ level. Interestingly, if I compare 2SLS

\footnotetext{
${ }^{34}$ Table A-11 reports the coefficients of $I V_{i, t}$ in the first-stage regressions. As expected, they are are always positive and significant at the $1 \%$ level.
} 
with OLS estimates, it is possible to observe that OLS coefficients are systematically smaller than those of the 2SLS, confirming that OLS coefficients might suffer from a downward bias.

As in Section 5.1, I evaluate the economic magnitude by calculating the percentage change in the employment growth rate induced by a one-standard-deviation increase in $\Delta A D_{i, t}$. The baseline estimate in column (3) of Table 3 indicates that an increase of one standard deviation in the duty increases employment by 0.07 percentage points per year. ${ }^{35}$ If I consider the estimates in column (4), a one-standard-deviation in the duty increases employment by 0.05 percentage points per year.

Similarly to the previous subsection, I run an additional set of robustness checks using alternative measures of AD protection. The results are presented in Table A-12. In all the specifications, AD has a positive and significant effect on US manufacturing employment.

Finally, I run a robustness check by augmenting the model presented in equation (5) with the pre-trend and production controls (Table A-14 in the Appendix); then, I check whether the results are robust when I control for the impact of all US TTBs against China on employment (Table A-13 in the Appendix). AD has still a positive impact on employment and this effect is significant at least at $5 \%$.

The last part of this subsection is devoted to the quantification of the size of AD protection's effect on US manufacturing employment. Using as a benchmark the results in columns (3) of Table 3, the economic magnitude of the 2SLS estimates is evaluated by building the counterfactual changes in employment that would have occurred in the absence of increased AD protection. Given that the dependent variable in equation (8) is the log-difference in employment, the coefficient $\beta_{1}$ is interpretable as the growth rate of employment continuously compounded.

To quantify the number of jobs gains due to AD protection, I apply the methodology of Acemoglu et al. (2016) and carry out the following counterfactual exercise:

$$
\text { Employment Gains }=\sum_{i, t} L_{i, t}\left(1-e^{-\beta_{1} \Delta \widetilde{A D}_{i, t}}\right)
$$

where $L_{i, t}$ is the employment level in industry $i$ at the end of term $t, \beta_{1}$ is the estimated coefficient of $\mathrm{AD}$ protection in the second stage, and $\Delta \widetilde{A D}_{i, t}$ is the actual change in $\mathrm{AD}$ protection, weighted by the partial $R^{2}$ in the first stage.

The implicit assumption behind this quantification exercise is that other factors influencing employment and the unobserved shocks estimated in the error term of equation (8) are not affected by an artificial reduction in $\mathrm{AD}$ protection.

Based on this counterfactual exercise, a gain of 35,000 jobs can be attributed to the direct effect of trade policy. ${ }^{36}$ To understand the size of this effect, recall that Acemoglu et al. (2016) estimated

\footnotetext{
${ }^{35}$ This number is obtained multiplying the estimated coefficient for $\Delta A D_{i, t}(0.06)$ by the standard deviation of the predicted $\Delta A D_{i, t}$ from the first stage (1.16).

${ }^{36}$ When looking at the entire sample period (1988-2016), I find a gain of 22,000 jobs in the protected industries.
} 
that the direct effect of exposure to Chinese import competition was a loss of 837,000 jobs from 1991 to 2011. It is also interesting to compare my counterfactual estimates with those of Bown et al. (2020), in which we use the same identification strategy of this paper to study the effects of protection along supply chains. For the period 1988-2016, we find that 570,000 US jobs were lost in downstream industries due to $\mathrm{AD}$ protection against China. Thus, the employment gains in the protected industries are more than offset by the losses in the rest of the economy.

\section{Conclusion}

Recent studies on the "China Syndrome" have examined the impact of Chinese import competition on US manufacturing jobs (e.g., Autor et al., 2013; Pierce and Schott, 2016; Acemoglu et al., 2016). These studies have abstracted from the role of protectionist policies, neglecting the extensive use of AD measures by the United States to shelter domestic industries from increased import competition.

In this paper, I study the effects of AD duties targeting Chinese firms on imports and employment in the protected sectors. To deal with concerns about the endogeneity of trade policy, I propose an instrumental variable strategy that exploits exogenous variation in supply and demand for $\mathrm{AD}$ protection.

I show that US AD duties have contained the rise of Chinese import competition. According to my baseline estimates, a one-standard-deviation increase in average AD duties decreased the annual growth rate of US imports from China by 0.40 percentage points on average. I then show that AD duties have smoothed the negative effects of import competition, increasing the annual growth rate of employment in manufacturing jobs by 0.07 percentage points.

The paper contributes to the ongoing policy and academic debates on the sustainability of the multilateral trading system. President Trump has argued that GATT/WTO rules do not allow governments to protect workers from unfair competition from China. He has instead resorted to unilateral protectionist measures, triggering a trade war with China. My empirical results show that temporary protectionist measures allowed by multilateral trade rules can actually shelter workers in sectors exposed to import competition from China, in line with theoretical studies on trade agreements by Bagwell and Staiger (1990).

My results should not be interpreted as providing a rationale for trade protection. It is well known that tariffs are the second-best policy instrument to help workers struggling in the face of import competition (Lipsey and Lancaster, 1956). My results indicate that trade policy had a limited impact on employment in protected industries. A more efficient strategy to protect workers would be to improve welfare programs directly aimed at helping displaced workers. ${ }^{37}$ Moreover,

\footnotetext{
${ }^{37}$ In the United States, the Trade Adjustment Assistance (TAA) program supports workers who lose their jobs or whose hours of work and wages are reduced as a result of increased imports. However, the program has not been effective at protecting workers from trade shocks (Autor et al., 2013).
} 
while import duties can benefit producers in the protected industries, they hurt final good consumers (e.g., Amiti et al., 2019) and firms in downstream industries (e.g., Bown et al., 2020).

\section{References}

Acemoglu, D., Autor, D. H., Dorn, D., Hanson, G. H., and Price, B. (2016). Import Competition and the Great US Employment Sag of the 2000s. Journal of Labor Economics, 34(S1):S141-S198.

Amiti, M., Dai, M., Feenstra, R. C., and Romalis, J. (2017). How Did China's WTO Entry Benefit US Consumers? NBER Working Paper No. 23487.

Amiti, M., Redding, S. J., and Weinstein, D. (2019). The Impact of the 2018 Trade War on U.S. Prices and Welfare. Journal of Economic Perspectives, 33(4):187-210. NBER Working Paper No. 25672.

Aquilante, T. (2018). Undeflected Pressure? The Protectionist Effect of Political Partisanship on US Antidumping Policy. European Journal of Political Economy, 55:455-470.

Autor, D. H., Dorn, D., and Hanson, G. H. (2013). The China Syndrome: Local Labor Market Effects of Import Competition in the United States. American Economic Review, 103(6):21212168.

Autor, D. H., Dorn, D., and Hanson, G. H. (2019). When Work Disappears: Manufacturing Decline and the Falling Marriage-Market Value of Men. American Economic Review: Insights, 1(2):161178.

Autor, D. H., Dorn, D., Hanson, G. H., and Majlesi., K. (2020). Importing Political Polarization? The Electoral Consequences of Rising Trade Exposure. American Economic Review. Forthcoming.

Bagwell, K. and Staiger, R. W. (1990). A Theory of Managed Trade. American Economic Review, 80(4):779-795.

Besedes, T. and Prusa, T. J. (2017). The Hazardous Effect of Antidumping. Economic Inquiry, $55(1): 9-30$.

Blonigen, B. A. (2006). Working the System: Firm Learning and the Antidumping Process. European Journal of Political Economy, 22:715-731.

Blonigen, B. A. and Park, J. H. (2004). Dynamic Pricing in the Presence of Antidumping Policy: Theory and Evidence. American Economic Review, 94(1):134-154.

Blonigen, B. A. and Prusa, T. J. (2016). Dumping and Antidumping Duties. In Bagwell, K. and Staiger, R. W., editors, Handbook of Commercial Policy, volume 1B, chapter 107-159. Elsevier.

Bown, C., Conconi, P., Erbahar, A., and Trimarchi, L. (2020). Trade Protection Along Supply Chains. Mimeo. 
Bown, C. P. (2014). Temporary Trade Barriers Database. Available at http://econ.worldbank.org/ttbd. The World Bank.

Bown, C. P. and Crowley, M. A. (2007). Trade Deflection and Trade Depression. Journal of International Economics, 72(1):176-201.

Bown, C. P. and Crowley, M. A. (2013). Self-Enforcing Trade Agreements: Evidence from TimeVarying Trade Policy. American Economic Review, 103(2):1071-1090.

Che, Y., Lu, Y., Pierce, J. R., Schott, P. K., and Tao, Z. (2016). Did Trade Liberalization with China Infuence US Elections? NBER Working Paper No. 22178.

Colantone, I., Crinò, R., and Ogliari, L. (2019). Globalization and Mental Distress. Journal of International Economics, 119(C):181-2007. Journal of International Economics.

Conconi, P., DeRemer, D., Kirchsteiger, G., Trimarchi, L., and Zanardi, M. (2017). Suspiciously Timed Trade Disputes. Journal of International Economics, 105:57-76.

Debaere, P. M. (2009). Fishy Issues: The U.S. Shrimp Antidumping Case. Darden Case No. UVA-G-0600.

Erbahar, A. and Zi, Y. (2017). Cascading Trade Protection: Evidence from the US. Journal of International Economics, 108C:274-299.

Fajgelbaum, P. D., Goldberg, P. K., Kennedy, P. J., and Khandelwal, A. K. (2020). The Return to Protectionism. Quarterly Journal of Economics, 135(1):1-55.

Feenstra, R. C. (1996). US Imports, 1972-1994: Data and Concordances. NBER Working Paper No. 5515 .

Felbermayr, G. and Sandkamp, A. (2020). The Trade Effects of Anti-Dumping Duties: Firm-level Evidence from China. European Economic Review. Forthcoming.

Finger, J. M., Blonigen, B. A., and Flynn, J. E. (1982). The Political Economy of Administered Protection. American Economic Review, 72(3):452-466.

Flaaen, A. and Pierce, J. R. (2019). Disentangling the Effects of the 2018-2019 Tariffs on a Globally Connected U.S. Manufacturing Sector. Finance and Economics Discussion Series 2019-086. Washington: Board of Governors of the Federal Reserve System.

Hansen, W. L. and Prusa, T. J. (1997). The Economics and Politics of Trade Policy: An Empirical Analysis of ITC Decision Making. Review of International Economics, 5(2):230-245.

Irwin, D. A. (2005). The Rise of US Anti-dumping Activity in Historical Perspective. The World Economy, 28(5):651-668. 
Irwin, D. A. (2017). Clashing over Commerce: A History of US Trade Policy. Markets and Governments in Economic History. University of Chicago Press.

Konings, J., Springael, L., and Vandenbussche, H. (2001). Import Diversion under European Antidumping Policy. Journal of Industry, Competition and Trade, 1(3):283-299.

Krueger, A. B. and Solow, R. M. (2001). The Roaring Nineties: Can full employment be sustained? Russell Sage Foundation and the Century Foundation Press, New York.

Lipsey, R. and Lancaster, K. (1956). The General Theory of Second Best. Review of Economic Studies, 24(1):11-32.

Lu, Y., Tao, T., and Zhang, Y. (2013). How Do Exporters Respond to Antidumping Investigations? Journal of International Economics, 91(2):290-300.

Ma, X. and McLaren, J. (2018). A Swing-State Theorem, with Evidence. NBER Working Paper No. 24425.

Moore, M. (1992). Rules or Politics? An Empirical Analysis of Antidumping Decisions. Economic Inquiry, 30(3):449-466.

Muûls, M. and Petropoulou, D. (2013). A Swing State Theory of Trade Protection in the Electoral College. Canadian Journal of Economics, 46(2):705-724.

Pierce, J. R. and Schott, P. K. (2016). The Surprisingly Swift Decline of US Manufacturing Employment. American Economic Review, 106(7):1632-1662.

Pierce, J. R. and Schott, P. K. (2020). Trade Liberalization and Mortality: Evidence from US Counties. American Economic Review: Insights, 2(1):47-64.

Prusa, T. (2001). On the Spread and Impact of Antidumping. Canadian Journal of Economics, $34(3): 591-611$.

Prusa, T. J. (1997). The Trade Effects of US Antidumping Actions. In Feenstra, R., editor, The Effects of US Trade Protection and Promotion Policies. University of Chicago Press, Chicago.

Trefler, D. (1993). Trade Liberalization and the Theory of Endogenous Protection: An Econometric Study of U.S. Import Policy. Journal of Political Economy, 101(1):138-160.

Vandenbussche, H. and Zanardi, M. (2010). The Chilling Trade Effects of Antidumping Proliferation. European Economic Review, 54(6):760-777.

Wooldridge, J. M. (2012). Introductory Econometrics: A Modern Approach. South-Western Pub, 5 th edition.

Zanardi, M. (2006). Antidumping: A Problem in International Trade. European Journal of Political Economy, 22(3):591-617. 


\section{Appendix}

Figure A-1: US AD duties, countervailing duties and safeguards in force against China (1988-2016)

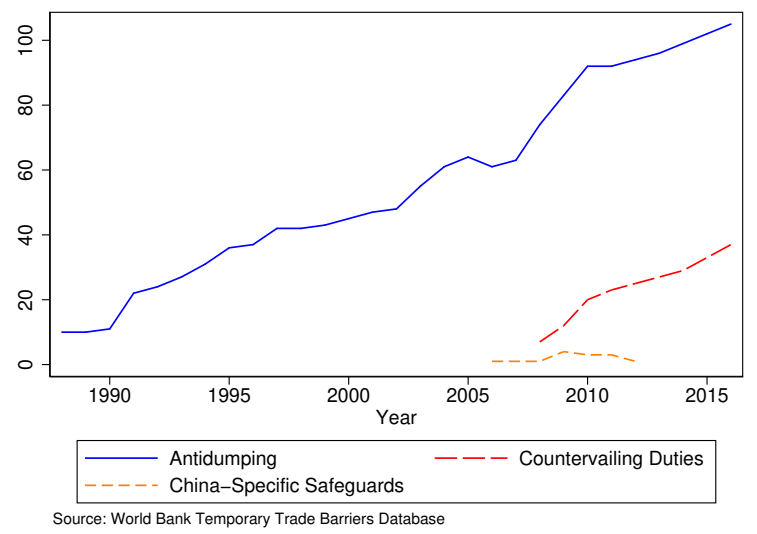

Figure A-2: Average AD duty in effect against China (1988-2016)

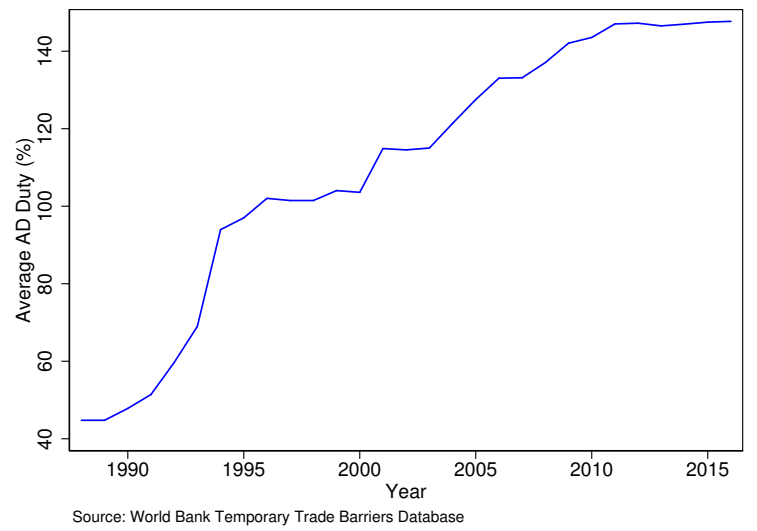


Figure A-3: AD measures in effect against China - Product Coverage (1988-2016)

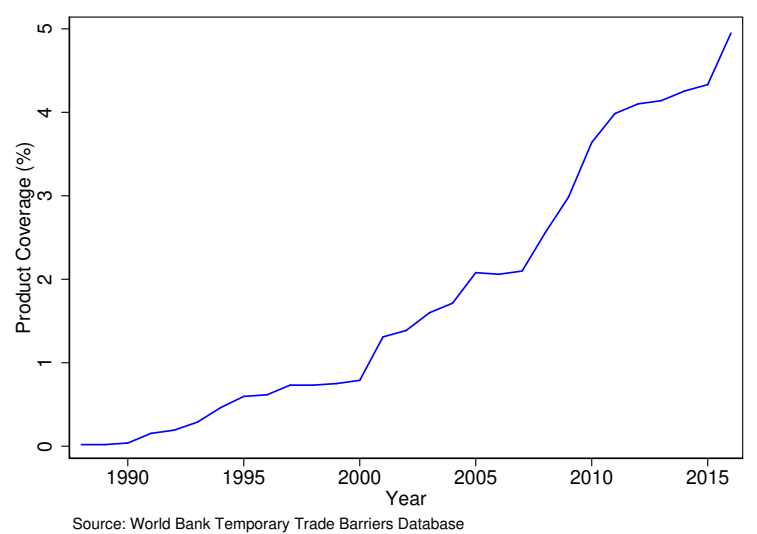

Figure A-4: Swing States in US presidential elections (1988 to 2012)

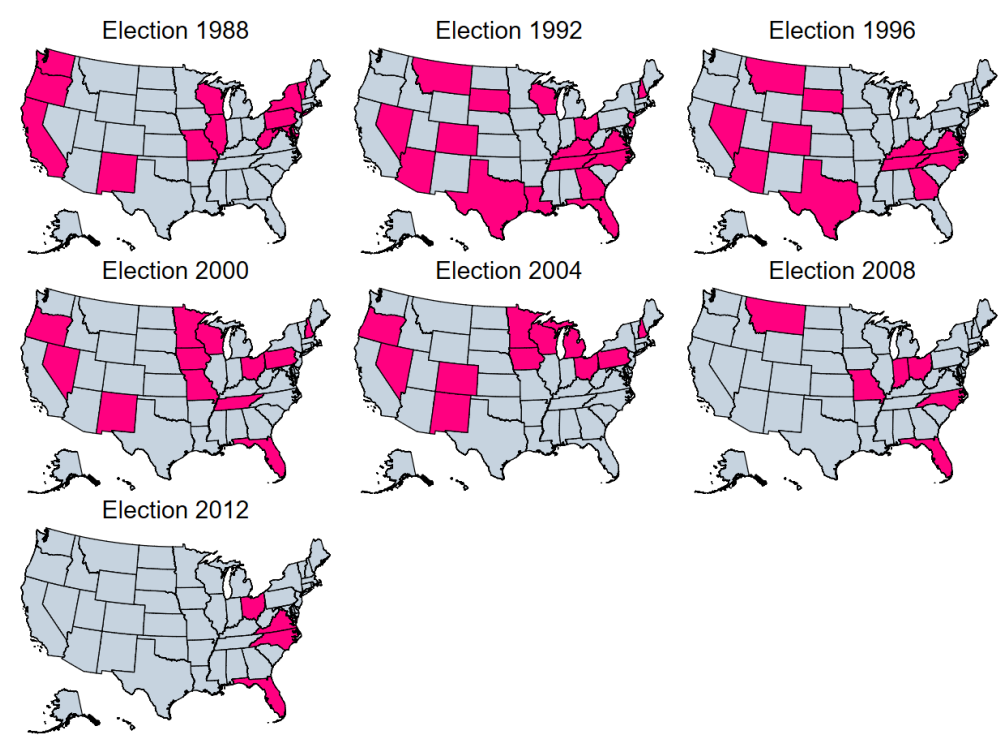

The maps indicate in pink the states classified as swing based on vote shares in the last eight presidential elections. 
Figure A-5: SIC4 employment shares by state

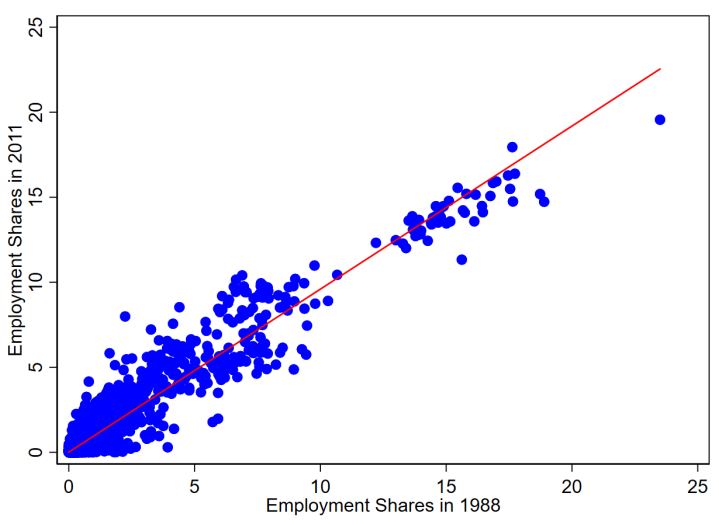

Notes: The figure plots state-level employment shares by SIC4 industry in 1988 and 2011, based on CPB data from Acemoglu et al. (2016).

Table A-1: Effect of $\mathrm{AD}$ on vote shares and on the identity of swing states

\begin{tabular}{lcc}
\hline \hline & $(1)$ & $(2)$ \\
& $\Delta{\text { Vote } \text { Share }_{s, t}}$ & Swing $_{s, t}$ \\
\hline$\Delta A D_{s, t}$ & -0.00 & $0.03^{* *}$ \\
& $(0.00)$ & $(0.01)$ \\
\hline State FE & Yes & Yes \\
Year FE & Yes & Yes \\
Span & $1988-2016$ & $1988-2016$ \\
Method & OLS & OLS \\
Adjusted R2 & 0.26 & 0.84 \\
Observations & 336 & 336 \\
\hline \hline
\end{tabular}

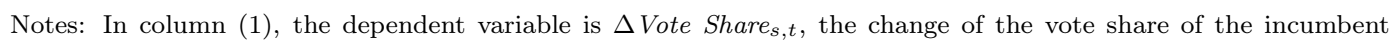
president's party in the presidential election in state $s$ during the presidential election in year $t$. In column (2), the dependent variable is $\operatorname{Swing}_{s, t}$, which is a dummy equal to one if state $s$ is classified as swing based on the vote shares of the presidential election in year $t$. The variable $\Delta A D_{s, t}$ is the change in $\mathrm{AD}$ protection at the state level during the four-year term before the presidential election in year $t$. Standard errors in parentheses are clustered at the state level. Significance levels: ${ }^{*} p<.10,{ }^{* *} p<.05,{ }^{* * *} p<.01$. 


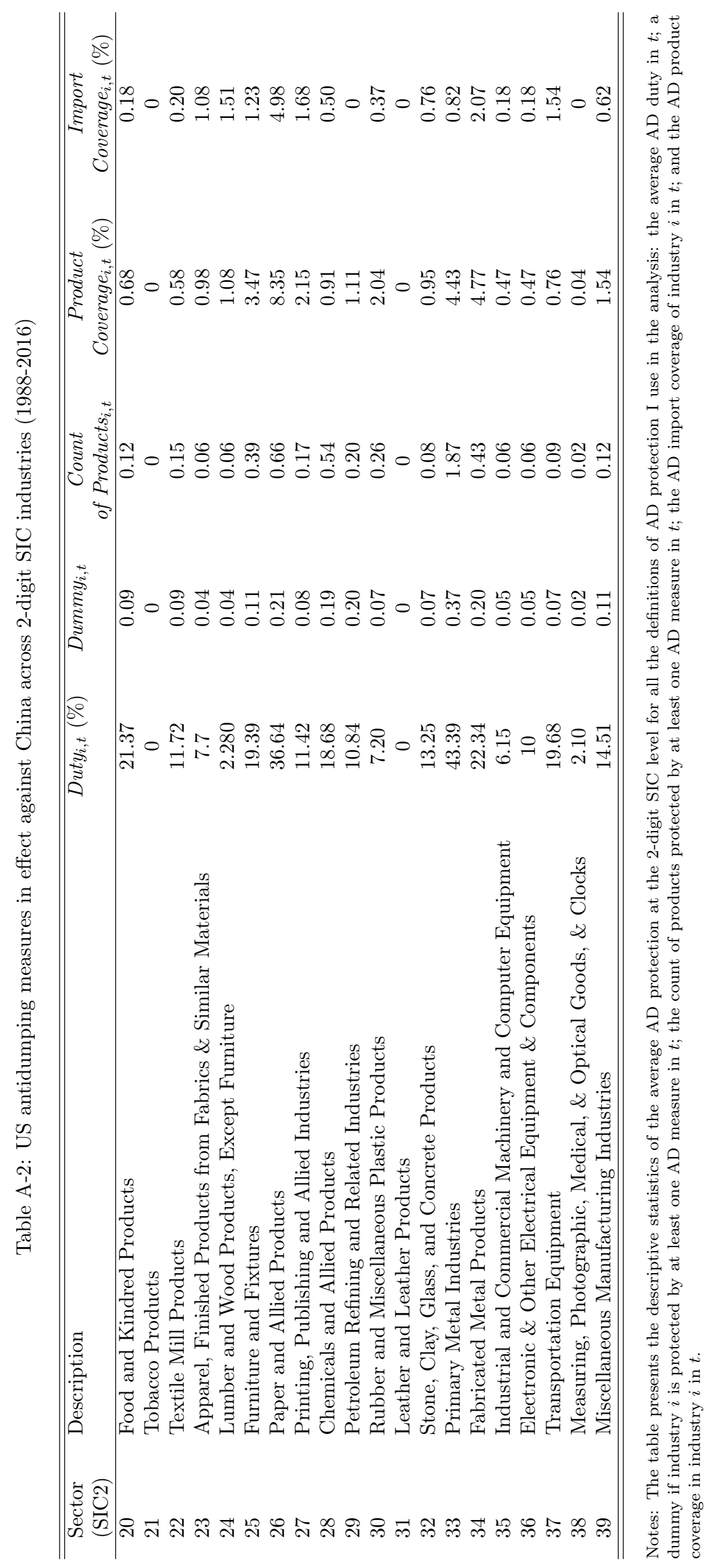


Table A-3: Swing Industry I $_{t}$ - Top 10 Sectors

\begin{tabular}{llccc}
\hline \hline Sector & Description & Swing Industry $_{i, t}$ & Experience $_{i}$ & Duty $_{i, t}(\%)$ \\
\hline 2752 & Commercial printing, lithographic & 0.0296 & 1 & 35.78 \\
3089 & Plastics products, n.e.c. & 0.0277 & 3 & 1.461 \\
2599 & Furniture and fixtures, n.e.c. & 0.0238 & 3 & 71.06 \\
3714 & Motor vehicle parts and accessories & 0.0229 & 8 & 142.9 \\
2711 & Newspapers & 0.0221 & 0 & 0 \\
3711 & Motor vehicles and car bodies & 0.0174 & 2 & 0 \\
3312 & Blast furnaces and steel mills & 0.0164 & 57 & 81.61 \\
3812 & Search and navigation equipment & 0.0148 & 0 & 0 \\
3499 & Fabricated metal products, n.e.c. & 0.0141 & 1 & 36.33 \\
3599 & Industrial machinery, n.e.c. & 0.0127 & 1 & 106.6 \\
\hline \hline
\end{tabular}

Notes: The table presents the descriptive statistics of the top-10 SIC4 sectors with the highest average value of Swing Industry $y_{i, t}$ during 1988-2016.

Table A-4: Experience $_{i}$ - Top 10 Sectors

\begin{tabular}{llccc}
\hline \hline Sector & Description & Swing Industry $_{i, t}$ & Experience $_{i}$ & Duty $_{i, t}(\%)$ \\
\hline 3312 & Blast furnaces and steel mills & 0.0164 & 57 & 81.61 \\
3714 & Motor vehicle parts and accessories & 0.0229 & 8 & 142.9 \\
3496 & Misc. fabricated wire products & 0.00288 & 6 & 114.7 \\
2869 & Industrial organic chemicals, n.e.c. & 0.00454 & 6 & 125.1 \\
2819 & Industrial inorganic chemicals, n.e.c. & 0.00410 & 5 & 68.95 \\
2241 & Narrow fabric mills & 0.00134 & 5 & 59.78 \\
3537 & Industrial trucks and tractors & 0.00150 & 4 & 0 \\
2399 & Fabricated textile products, n.e.c. & 0.00154 & 4 & 59.78 \\
3991 & Brooms and brushes & 0.000778 & 4 & 189.6 \\
3069 & Fabricated rubber products, n.e.c. & 0.00708 & 4 & 0 \\
\hline \hline
\end{tabular}

Notes: The table presents the descriptive statistics of the top-10 SIC4 sectors with the highest average value of Experience $_{i}$ defined between 1980-1987. 
Table A-5: Descriptive statistics

\begin{tabular}{lccccc}
\hline \hline & Mean & S.D. & Median & Min & Max \\
\hline$\Delta L_{i, t}$ & -2.82 & 5.95 & -2.08 & -74.20 & 23.03 \\
$\Delta$ Import $_{i, t}$ & 17.57 & 26.21 & 14.64 & -152.18 & 258.94 \\
$\Delta$ Duty $_{i, t}$ & 1.57 & 10.00 & 0.00 & -40.62 & 107.49 \\
$\Delta$ Dummy $_{i, t}$ & 0.03 & 0.20 & 0.00 & -1 & 1 \\
$\Delta$ Count of Products $_{i, t}$ & 0.02 & 0.20 & 0 & -0.50 & 6.50 \\
$\Delta$ Product Coverage $_{i, t}$ & 0.16 & 1.29 & 0 & -6.25 & 25 \\
$\Delta$ Import Coverage $_{i, t}$ & 0.12 & 1.04 & 0 & -6.53 & 22.11 \\
$\Delta$ IV $_{i, t}$ & 0.01 & 0.60 & 0.00 & -9.09 & 22.57 \\
\hline Observations & & \multicolumn{5}{c}{} \\
\hline \hline
\end{tabular}

Notes: The table presents the descriptive statistics regarding the key variables used in the empirical analysis. $\Delta L_{i, t}$ is the annual growth rate of US employment in industry $i$ defined as the log difference during term $t$. $\Delta I m p o r t s_{i, t}$ is the annual growth rate of US imports from China for industry $i$ defined as the log difference during a presidential term $t$. Statistics are provided for all the definitions of AD protection used in the analysis: the average AD duty; a dummy equal to 1 if industry $i$ is protected by at least one AD measure; the count of products protected by at least one $\mathrm{AD}$ measure; the $\mathrm{AD}$ product coverage in industry $i$; and the $\mathrm{AD}$ import coverage of industry $i$. The endogenous variable $\Delta A D_{i, t}$ is instrumented using $\Delta I V_{i, t}$, which is the change in the level of the proposed instrument (defined in equation (4)) during term $t$ relative to the level in $t-1$.

Table A-6: First stage of 2SLS regressions of Table 1

\begin{tabular}{lcc}
\hline \hline & $(1)$ & $(2)$ \\
& Duty $y_{i, t}$ & Duty $y_{i, t}$ \\
\hline$\Delta I V_{i, t}$ & $1.82^{* * *}$ & $1.69^{* * *}$ \\
& $(0.30)$ & $(0.18)$ \\
\hline Industry x Term FE & Yes & Yes \\
Span & $1992-2012$ & $1992-2016$ \\
Observations & 1,618 & 1,948 \\
\hline \hline
\end{tabular}

Notes: The endogenous variable in the estimation of equation (4) is $A D_{i, t}$, the measure of antidumping protection. Estimates of the first-stage are provided for AD defined as the average AD duty in $t$. Industry $\times$ Term fixed effects are included in all the specifications. Standard errors in parentheses are clustered at the 3-digit SIC level. Significance levels: ${ }^{*} p<.10,{ }^{* *} p<.05,{ }^{* * *} p<.01$. 
Table A-7: Estimation of the effect of AD on US imports from China (including zeros)

\begin{tabular}{lcccc}
\hline \hline & $(1)$ & $(2)$ & $(3)$ & $(4)$ \\
& Duty $y_{i, t}$ & Duty, & Duty & \\
& -0.06 & -0.03 & $-0.37^{* *}$ & $-0.27^{* *}$ \\
\hline$A D_{i, t}$ & $(0.10)$ & $(0.09)$ & $(0.15)$ & $(0.12)$ \\
\hline Industry $\times$ Term FE & Yes & Yes & Yes & Yes \\
Span & $1992-2012$ & $1992-2016$ & $1992-2012$ & $1992-2016$ \\
Method & OLS & OLS & 2 SLS & 2 SLS \\
Adjusted R2 & 0.21 & 0.22 & & \\
F-statistic & & & 36.62 & 83.98 \\
Observations & 1,675 & 2,010 & 1,675 & 2,010 \\
\hline \hline
\end{tabular}

Notes: The dependent variable $\Delta$ Imports $_{i, t}$ is the annual growth rate of US imports from China for industry $i$ defined as the difference in log of one plus the imports during a presidential term $t$. Estimates of the coefficient $\beta_{1}$ of equation (5) are provided for AD defined as the average AD duty in $t$. Industry $\times$ Term fixed effects are included in all the specifications. Standard errors in parentheses are clustered at the 3-digit SIC level. Significance levels: * $p<.10,{ }^{* *} p<.05,{ }^{* * *} p<.01$. 
Table A-8: Effect of AD on imports from China: alternative definitions of AD

\begin{tabular}{|c|c|c|c|c|}
\hline & \multicolumn{2}{|c|}{ Dummy $_{i, t}$} & \multicolumn{2}{|c|}{ Count of Products $s_{i, t}$} \\
\hline & $(1)$ & $(2)$ & $(3)$ & $(4)$ \\
\hline \multirow[t]{2}{*}{$\overline{\Delta A D_{i, t}}$} & $-11.07^{* * *}$ & $-7.61^{* *}$ & $-2.26^{* * *}$ & $-2.60^{* * *}$ \\
\hline & $(3.84)$ & $(3.43)$ & $(0.51)$ & $(0.91)$ \\
\hline Industry $\times$ Term FE & Yes & Yes & Yes & Yes \\
\hline Span & $1992-2012$ & $1988-2016$ & 1992-2012 & $1988-2016$ \\
\hline Method & 2SLS & 2SLS & 2SLS & 2SLS \\
\hline F-statistic & 19.32 & 20.37 & 147.32 & 149.70 \\
\hline \multirow[t]{3}{*}{ Observations } & 1,618 & 1,948 & 1,618 & 1,948 \\
\hline & \multicolumn{2}{|c|}{ Product Coverage $_{i, t}$} & \multicolumn{2}{|c|}{ Import Coverage $_{i, t}$} \\
\hline & $(1)$ & $(2)$ & $(3)$ & $(4)$ \\
\hline \multirow[t]{2}{*}{$\Delta A D_{i, t}$} & $-6.23^{* * *}$ & $-4.53^{* *}$ & $-14.39^{* * *}$ & $-8.25^{* *}$ \\
\hline & $(1.61)$ & $(1.78)$ & $(3.78)$ & $(3.15)$ \\
\hline Industry $\times$ Term FE & Yes & Yes & Yes & Yes \\
\hline Span & $1992-2012$ & $1992-2016$ & $1992-2012$ & $1992-2016$ \\
\hline Method & 2SLS & 2SLS & 2SLS & 2SLS \\
\hline F-statistic & 35.35 & 24.76 & 19.75 & 18.91 \\
\hline Observations & 1,618 & 1,948 & 1,618 & 1,948 \\
\hline
\end{tabular}

Notes: The dependent variable $\Delta$ Imports $_{i, t}$ is the annual growth rate of US imports from China for industry $i$ defined as the $\log$ difference during a presidential term $t$. Estimates of the coefficient $\beta_{1}$ of equation (5) are provided for two alternative definitions of $\mathrm{AD}$ protection: a dummy if industry $i$ is protected by at least one AD measure in $t$; and the number of products protected by at least one AD measure in $t$. Industry $\times$ Term fixed effects are included in all the specifications. Standard errors in parentheses are clustered at the 3-digit SIC level. Significance levels: * $p<.10,{ }^{* *} p<.05,{ }^{* * *} p<.01$. 
Table A-9: Effect of AD on imports from China: All TTBs

\begin{tabular}{|c|c|c|c|c|}
\hline & $(1)$ & $(2)$ & (3) & (4) \\
\hline & Duty $_{i, t}$ & Duty $_{i, t}$ & Duty $_{i, t}$ & Duty $y_{i, t}$ \\
\hline \multirow[t]{2}{*}{$\overline{\Delta A D_{i, t}}$} & $-0.09^{* *}$ & -0.06 & $-0.34^{* * *}$ & $-0.24^{* *}$ \\
\hline & $(0.05)$ & $(0.05)$ & $(0.13)$ & $(0.10)$ \\
\hline Industry $\times$ Term FE & Yes & Yes & Yes & Yes \\
\hline Pretrend Controls & Yes & Yes & Yes & Yes \\
\hline Production Controls & Yes & Yes & Yes & Yes \\
\hline Span & $1992-2012$ & $1992-2016$ & $1992-2012$ & $1992-2016$ \\
\hline Method & OLS & OLS & 2SLS & 2SLS \\
\hline Adjusted R2 & 0.29 & 0.31 & & \\
\hline F-statistic & & & 36.49 & 84.28 \\
\hline Observations & 1,618 & 1,948 & 1,618 & 1,948 \\
\hline
\end{tabular}

Notes: The dependent variable $\Delta$ Imports $_{i, t}$ is the annual growth rate of US imports from China for industry $i$ defined as the $\log$ difference during a presidential term $t$. Estimates of the coefficient $\beta_{1}$ of equation (5) are provided for TTBs protection defined as the average TTB duty in $t$. Industry $\times$ Term fixed effects are included in all the specifications. Standard errors in parentheses are clustered at the 3-digit SIC level. Significance levels: ${ }^{*} p<.10,{ }^{* *}$ $p<.05,{ }^{* * *} p<.01 . p<.01$. 
Table A-10: Effect of AD on imports from China: additional industry controls

\begin{tabular}{lcccc}
\hline \hline & $(1)$ & $(2)$ & $(3)$ & $(4)$ \\
& Duty $_{i, t}$ & Duty $_{i, t}$ & Duty $_{i, t}$ & Duty $_{i, t}$ \\
\hline$\Delta A D_{i, t}$ & $-0.11^{* *}$ & -0.07 & $-0.47^{* * *}$ & $-0.30^{* * *}$ \\
& $(0.05)$ & $(0.05)$ & $(0.07)$ & $(0.09)$ \\
\hline Industry $\times$ Term FE & Yes & Yes & Yes & Yes \\
Pretrend Controls & Yes & Yes & Yes & Yes \\
Production Controls & Yes & Yes & Yes & Yes \\
Span & $1992-2012$ & $1992-2016$ & $1992-2012$ & $1992-2016$ \\
Method & OLS & OLS & 2 SLS & 2 SLS \\
Adjusted R2 & 0.29 & 0.31 & & 60.98 \\
F-statistic & & & 15.18 & 1,948 \\
Observations & 1,618 & 1,948 & 1,618 & \\
\hline \hline
\end{tabular}

Notes: The dependent variable $\Delta$ Imports $_{i, t}$ is the annual growth rate of US imports from China for industry $i$ defined as the $\log$ difference during a presidential term $t$. Estimates of the coefficient $\beta_{1}$ of equation (5) are provided for $\mathrm{AD}$ defined as the average AD duty in $t$. Pre-trend and production controls are included in all four specifications. Industry $\times$ Term fixed effects are included in all the specifications. Standard errors in parentheses are clustered at the 3-digit SIC level. Significance levels: ${ }^{*} p<.10,{ }^{* *} p<.05,{ }^{* * *} p<.01$.

Table A-11: First stage of 2SLS regression in Table 3

\begin{tabular}{lcc}
\hline \hline & $(1)$ & $(2)$ \\
& Duty & Duty \\
\hline$\Delta I V_{i, t}$ & $1.82^{* * *}$ & $1.32^{* * *}$ \\
& $(0.30)$ & $(0.13)$ \\
\hline Industry $\times$ Term FE & Yes & Yes \\
Span & $1992-2012$ & $1992-2016$ \\
Observations & 1,689 & 2,364 \\
\hline \hline
\end{tabular}

Notes: The endogenous variable in the estimation of equation (8) is $A D_{i, t}$, my measure of AD protection. Estimates of the first stage are provided for $\mathrm{AD}$, defined as the average $\mathrm{AD}$ duty in $t$. Industry $\times$ Term fixed effects are included in all the specifications. Standard errors in parentheses are clustered at the 3-digit SIC level. Significance levels: * $p<.10,{ }^{* *} p<.05,{ }^{* * *} p<.01$. 
Table A-12: Effect of $\mathrm{AD}$ on employment: alternative definitions of $\mathrm{AD}$

\begin{tabular}{lcccc}
\hline \hline & & & \multicolumn{2}{c}{ Count of Products ${ }_{i, t}$} \\
& $(1)$ & $(2)$ & $(3)$ & $(4)$ \\
\hline$\Delta A D_{i, t}$ & $2.31^{* * *}$ & $2.35^{* * *}$ & $0.47^{* * *}$ & $0.80^{* * *}$ \\
& $(0.51)$ & $(0.48)$ & $(0.14)$ & $(0.21)$ \\
\hline Industry $\times$ Term FE & Yes & Yes & Yes & Yes \\
Span & $1992-2012$ & $1988-2016$ & $1992-2012$ & $1988-2016$ \\
Method & 2 SLS & 2 SLS & 2 SLS & 2 SLS \\
F-statistic & 19.35 & 22.88 & 147.36 & 206.49 \\
Observations & 1,689 & 2,364 & 1,689 & 2,364 \\
\hline \hline & Product Coverage $i, t$ & Import Coverage & \\
& $(1)$ & $(2)$ & $(3)$ & $(4)$ \\
\hline$\Delta A D_{i, t}$ & $1.30^{* * *}$ & $1.39^{* * *}$ & $3.00^{* *}$ & $2.56^{* * *}$ \\
& $(0.43)$ & $(0.38)$ & $(1.26)$ & $(0.82)$ \\
\hline Industry $\times$ Term FE & Yes & Yes & Yes & Yes \\
Span & $1992-2012$ & $1992-2016$ & $1992-2012$ & $1992-2016$ \\
Method & 2 SLS & $2 S L S$ & $2 S L S$ & $2 S L S$ \\
F-statistic & 35.72 & 28.55 & 19.90 & 19.43 \\
Observations & 1,689 & 2,364 & 1,689 & 2,364 \\
\hline \hline
\end{tabular}

Notes: The dependent variable $\Delta L_{i, t}$ is the annual growth rate of US employment in industry $i$ defined as the log difference during a period $t$. Estimates of the coefficient $\beta_{1}$ of equation (8) are provided for two alternative definitions of AD protection: a dummy if industry $i$ is protected by at least ne AD measure in $t$; and the number of products protected by at least one AD measure in $t$. Standard errors in parentheses are clustered at the 3-digit SIC level. Significance levels: ${ }^{*} p<.10,{ }^{* *} p<.05,{ }^{* * *} p<.01$. 
Table A-13: Effect of AD on employment: all TTBs

\begin{tabular}{lcccc}
\hline \hline & $(1)$ & $(2)$ & $(3)$ & $(4)$ \\
& Duty & & Duty \\
& $0.02^{*}, t$ & $0.02^{*}$ & $0.06^{* * *}$ & $0.06^{* * *}$ \\
& $(0.01)$ & $(0.01)$ & $(0.01)$ & $(0.01)$ \\
\hline Industry $\times$ Term FE & Yes & Yes & Yes & Yes \\
Pretrend Controls & Yes & Yes & Yes & Yes \\
Production Controls & Yes & Yes & Yes & Yes \\
Span & $1992-2012$ & $1988-2016$ & $1992-2012$ & $1988-2016$ \\
Method & OLS & OLS & 2 SLS & 2 SLS \\
Adjusted R2 & 0.42 & 0.42 & & 111.79 \\
F-statistic & & & 36.63 & 2,364 \\
Observations & 1,689 & 2,364 & 1,689 & \\
\hline \hline
\end{tabular}

Notes: The dependent variable $\Delta L_{i, t}$ is the annual growth rate of US employment im industry $i$ defined as the log difference during a period $t$. Estimates of the coefficient $\beta_{1}$ of equation (8) are provided for TTBs protection defined as the average TTB duty in $t$. Industry $\times$ Term fixed effects are included in all the specifications. Standard errors in parentheses are clustered at the 3 -digit SIC level. Significance levels: ${ }^{*} p<.10,{ }^{* *} p<.05,{ }^{* * *} p<.01$. 
Table A-14: Effect of AD on employment: additional industry controls

\begin{tabular}{lcccc}
\hline \hline & $(1)$ & $(2)$ & $(3)$ & $(4)$ \\
& Duty & & Duty \\
& $0.02^{*}$ & 0.02 & $0.11^{* * *}$ & $0.12^{* * *}$ \\
& $(0.01)$ & $(0.01)$ & $(0.03)$ & $(0.03)$ \\
\hline Industry $\times$ Term FE & Yes & Yes & Yes & Yes \\
Pretrend Controls & Yes & Yes & Yes & Yes \\
Production Controls & Yes & Yes & Yes & Yes \\
Span & $1992-2012$ & $1988-2016$ & $1992-2012$ & $1988-2016$ \\
Method & OLS & OLS & 2 SLS & 2 SLS \\
Adjusted R2 & 0.43 & 0.43 & & \\
F-statistic & & & 15.12 & 47.81 \\
Observations & 1,689 & 2,364 & 1,689 & 2,364 \\
\hline \hline
\end{tabular}

Notes: The dependent variable $\Delta L_{i, t}$ is the annual growth rate of US employment in industry $i$ defined as the log difference during a period $t$. Estimates of the coefficient $\beta_{1}$ of equation (8) are provided for AD, defined as the average AD duty in $t$. Pre-trend and production controls are included in all four specifications. Industry $\times$ Term fixed effects are included in all the specifications. Standard errors in parentheses are clustered at the 3-digit SIC level. Significance levels: ${ }^{*} p<.10,{ }^{* *} p<.05,{ }^{* * *} p<.01$. 